VOL. 6

No. 6

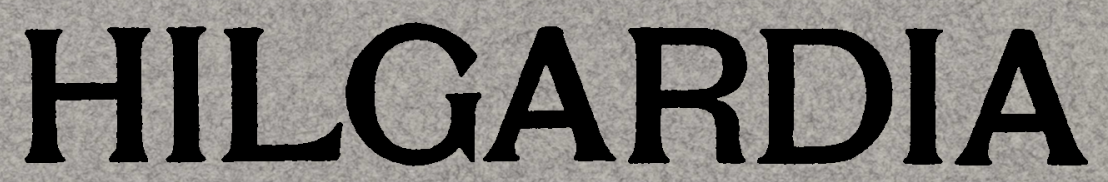

A Journal of Agricultural Science

PUBLISHED BY THE

California Agricultural Experiment Station

\author{
CONTENTS
}

Effect of Paper Mulches on Soil Temperature, Soil Moisture, and Yields of Certain Crops

ALFRED SMITH

UNIVERSITY OF CALIFORNIA PRINTING OFFICE BERKELEY, CALIFORNIA 
The titles of the Technical Papers of the Californil Agricultural Experiment Btation, Nos. 1 to 20, which HILGARDIA replaces, and copies of which may be had on application to the Publication Secretary, Agricultural Experiment Btation, Berkeloy, are as follows:

4. Effect of Bodium Chlorid and Calcium Chlorid upon the Growth and Composition of Young Orange Trees, by H. 8. Beed and A. R. C. Haas. Apr-11, 1923.

5. Citrus Blast and Black Pit, by I. B. Fawcett, W. T. Horne, and A. F. Camp. May, 1823.

B. A Study of Deciduous Fruit Tree Rootstocks with spectal Reference to Their Identification, by Myer J. Heppner. June, 1923.

7. A study of the Darkening of Apple Tiasue, by E. I. Overholser and W. $\nabla$. Cruess. June, 1923.

8. Effect of Balts on the Intake of Inorganic Elements and on the Buffer Bystem of the Plant, by D. R. Hoagland and J. O. Martin. July, 1828.

9. Experiments on the Roclamation of Alkali 8olls by Leaching with Water and Gypsum, by P. I Eibbard. Angust, 1923.

10. The Seasonal Variation of the soil Moisture in a Wainut Grove in Relation to Hygroscopic Coefficient, by L. D. Batchelor and FI. 8. Reed. Beptember, 1923.

11. Studies on the Effects of Sodium, Potassium, and Oalcium on Young Orange Trees, by II. B. Boed and A. B. O. Haas. October, 1923.

12. The Effect of the Plant on the Beaction of the Oulture Solution, by $D$. Hoagland. November, 1923.

14. The Respiration of Potato Tubers in Belation to the Occurrence of Blackheart, by J. P. Bennett and E. T. Bartholomew. January, 1924.

16. The Molsture Equivalent as Influenced by the Amount of Botl Used in its Determination, by F. J. Voihmejer, O. W. Israeisen and J. P. Conrad. Soptember, 1924.

17. Nutrient and Toxdc Effects of Certain Ions on Citrus and Wainnt Trees with Especial Reference to the Concentration and Ph of the Medium, by H. 8. Beed and A. R. C. Haas. October, 1824.

18. Factors Influencing the Rate of Cermination of Beed of Asparagus Offelnalis, by H. A Borthwick. March, 1925.

19. The Relation of the Subcutaneous Administration of Iiving Bacterinm abortum to the Immunity and Carrier Problem of Bovine Infectious Abortion, by George H. Flart and Jacob Traum. April, 1925.

20. A study of the Conductive Tissues in Bhoots of the Bartlett Pear and the Relationship of Food Movement to Dominance of the Aplesl Buds, by Frank E. Cardaer. Aprll, 1925. 


\title{
HILGARDIA
}

\author{
A JOURNAL OF AGRICULTURAL SCIENCE
}

PUBLISHED BY THE

CALIFORNIA AGRICULTURAL EXPERIMENT STATION

VOL. 6

NOVEMBER, 1931

No. 6

\section{EFFECT OF PAPER MULCHES \\ ON SOIL TEMPERATURE, SOIL MOISTURE, AND YIELDS OF CERTAIN CROPS}

ALFRED SMITH1

\section{INTRODUCTION}

The first large commercial use of paper as a soil covering or 'mulch' was made in 1914 by C. F. Eckart, manager of the Olaa Sugar Company in Hawaii, where it was found that when the mulch paper was applied over the row of seed cane, injury from weed growth was reduced. The use of mulch paper on sugar cane has not developed, but it has been found very useful in pineapple culture and is used at present (1931) on approximately 80 per cent of the pineapples grown in Hawaii.

Hartung ${ }^{(6)}$ experimented with paper mulch as a surface covering in connection with problems dealing primarily with the use of fertilizers in the production of pineapples. The paper which he used was made of raw paper felt stock saturated with asphalt and coated with asphalt on both sides of the sheet and given a light coating of talc or soapstone which gave it a grayish brown color. He found that perforated paper did not control weeds as efficiently as nonperforated paper, and that the available soil moisture during a period of 159 days was practically the same under the perforated and nonperforated papers. Where the nonperforated mulching paper was used, he found that ammonification and nitrification of organic and ammoniacal nitrogen was more uniform, and that the soil-moisture content was

1 Associate Professor of Soil Technology and Associate Soil Technologist in the Experiment Station. 
maintained in a more favorable condition for plant growth than had hitherto been achieved in general pineapple culture. When black paper was used, the soil at a depth of 3 inches was from $3.0^{\circ}$ to $4.5^{\circ} \mathrm{F}$ warmer and there was an increase of 20 to 25 per cent in crop yield.

In 1926 the Society of Manufacturers of Roofing Paper conducted tests with paper mulches on about twenty-five farms and nursery experimental stations throughout Germany, using over twenty different crops as indicators. They found that the paper maintained a better soil structure and increased the soil temperature approximately $4^{\circ}$ to $5^{\circ} \mathrm{F}$. Difficulty was experienced with plants turning yellow and wilting when tarred roofing paper was used. These harmful effects were believed to be due both to light-absorbing qualities and some chemical properties of the tarred paper. On account of these effects it was suggested that crude tar should not be used in the manufacture of mulch paper. Crop increases were obtained with the use of mulch paper on melons, cucumbers, and tomatoes. These investigators suggested that the strength of the paper and its durability need further investigation in order to determine whether the use of the paper mulch would prove profitable and practicable.

Shaw ${ }^{(11)}$ at Berkeley, California, using nonperforated paper impregnated and coated on both sides with asphaltic material, found that at a depth of 3 inches below the surface "the covered plot averaged about 0.42 degree per hour warmer than the bare plot." He determined that in the surface 18 inches of soil, under the paper mulch, there was from 0.5 to 4.0 per cent more moisture than in the bare plots 6 weeks after the paper mulch had been applied. The crop yields of beans, milo maize, and potatoes indicated that under Berkeley conditions the paper covering did not favorably affect these crops.

Under field conditions in Hawaii, Stewart, Thomas, and Horner, ${ }^{(15)}$ using a heavy grade of asphalt-impregnated and coated paper, determined the effect upon soil temperature, moisture, and nitrification. Temperatures were measured at a depth of 4 inches below the surface and the greatest difference between the paper-mulched and bare soil occurred during July, August, and September, and varied from $4^{\circ}$ or $5^{\circ} \mathrm{F}$ during the night to frequently as high as $12^{\circ}$ to $15^{\circ} \mathrm{F}$ in the afternoon. During the winter months the temperature differences were not so great. They found that in the surface foot of soil the moisture content was greater under the paper mulch than in the bare plots. The higher nitrate content found in the paper-mulched soils seemed to indicate a more rapid elaboration of the principal soil nutrients. The pineapples were 30 to 40 per cent heavier when grown with the paper mulch. 
Smith ${ }^{(13)}$ has reported soil temperatures obtained by use of electrical resistance thermometers under paper mulches of different colors, nonperforated and perforated. In his data obtained at Davis, California, for the warmest week in July, 1925, the temperatures at depths of 3 and 12 inches were the highest in the area covered with nonperforated black paper and the lowest under the perforated gray paper.

As a result of four seasons' work at Rosslyn, Virginia, with paper mulch, Flint ${ }^{(3)}$ found, with only two exceptions, a stimulation in crop growth with the use of paper mulch. He also found perforated paper to be unsatisfactory on account of weed growth which developed through the perforations. In addition to the direct effect on yield, the nonperforated paper reduced the necessary weeding, thus adding considerably to its economic value. Flint's findings agreed with those previously reported by Smith in that the moisture conservation due to paper mulching did not extend beyond the depth of 4 inches. Flint ${ }^{(3)}$ and Magruder ${ }^{(9)}$ were unable to detect a greater quantity of available nitrates in the paper-mulched soil than in the unmulched soil. By the Hoffer test, Flint found that plants grown with paper mulch were higher in nitrates, while the control plants indicated either no excess nitrates or only a very slight trace. He concluded that any impervious dark paper free from toxic substances such as tar, may be as efficient in stimulating plant growth as those which are specially prepared for mulching purposes.

In a later publication ${ }^{(4)}$ by Flint, it was recommended that because so little is known concerning the economic value of paper mulches, they should be tried only on a small scale and on crops having a high value. He also points out that the introduction of paper mulch into the pineapple industry of the Hawaiian Islands did not result in the reduction of the application of manures or commercial fertilizers, but it did enhance the effectiveness of fertilizers.

Edmond ${ }^{(2)}$ used mulch paper on a fertilized sandy loam soil, and obtained an increase in the yield of cabbage, tomatoes, and peppers, and an increase in both yield and earliness of beans, cucumbers, and sweet corn. Of the crops mentioned, cucumbers produced the greatest increase and sweet corn the least. There was no marked influence of the paper mulch on the yield of lettuce. He stated that paper mulch should be used in an experimental way only until its practical use is definitely established.

Hall $^{2}$ experimented in South Carolina and New York in 1908 and 1909 with aluminum phosphate, which when acidified made a 'muck'

${ }^{2}$ William A. Hall. La Grande Estrade, Marignane, B. du Rh., France. Private correspondence. 
that did not dry out. This material, worked into a fibrous body, made a transportable mulch into which he later embodied potash and nitrate. During the last nine years he has been carrying on mulching tests in southern France and has developed a mulching paper that can be worked into the soil for a fertilizer when its need for a mulch has passed. He has manufactured mats from seaweed which are reported to contain 5 to 7 per cent of potash, a fair amount of fixed nitrogen, chlorides of magnesium and sodium, and proteins and vegetable fatty matter, and are reported to be of considerable value as fertilizers.

The most general use of paper mulch at the present time is in the pineapple industry of the Hawaiian Islands, where an asphalt-impregnated, nonperforated black paper is used. Ammonium sulfate is applied as fertilizer both before the paper is laid and also around the basal leaves after the mulch is in place.

\section{REASONS FOR THE INVESTIGATION}

Heretofore most of the paper-mulch work has been in connection with its effect on crop yield, whereas in this work particular emphasis has been placed on soil temperature, soil moisture, and the effects of different types, grades, and colors of paper. Certain crops were used as indicators and the effect of the different papers and methods of laying them were carefully noted, but no attempt has yet been made to determine which of the many California crops will give the greatest response to this treatment or to go deeply into the economics of the use of paper mulch under California conditions.

\section{LOCATION OF EXPERIMENTAL SITE}

After much detailed examination an area of nearly uniform soil was selected which has a smooth surface with a slope to the southeast ranging from 5 to 10 feet per mile. The soil is the Yolo loam, an unweathered material of alluvial origin derived mainly from sedimentary rocks. The surface soil is a loam having a volume weight of 1.10. At a depth of 3 feet it is underlaid by a fine sandy loam having a volume weight of 1.13. Occasionally, at about 60 inches, sand is found. The surface water table is normally about 20 feet below the surface, and water in sufficient quantity for irrigation at approximately 120 feet. Shaw and Smith ${ }^{(12)}$ found that for Yolo loam "water tables at 10 feet or more below the surface would be below 
the maximum height of capillary rise and would result in no movement of water to the surface." The area was subdivided into 16 plots, 5 meters square, with a path 2 meters wide on the four sides of each plot.

\section{INSTALLATION OF ELECTRICAL RESISTANCE THERMOMETERS}

Soil temperatures were obtained by the use of electrical resistance thermometers, and an automatic Leeds and Northrup temperature recorder. Sixteen such thermometers were installed in five different plots and were standardized against standard mercury thermometers, and it is believed that all temperature data herein reported are aceurate to within $0.5^{\circ} \mathrm{F}$. The recorder was run continuously and adjusted so that the temperature of an individual thermometer would be registered every 15 minutes.

\section{PAPER MULCH TRIALS IN 1925}

In the first trials with paper mulch, no crop was grown because it was desired to obtain some information relative to the effect of paper mulch on soil temperature and soil moisture without interference by the shading effect of a crop. Figure 1 is a view of the experimental area showing clearly the different papers used.

Before laying the paper, the soil was worked into a granular condition and the plots were made practically level. The paper mulch was put on during the first week of May, in strips 36 inches wide with a lap of 3 inches. It was held in place by 11/4-inch redwood battens, placed over the lap and stapled with wire to the ground. The different kinds of paper mulch used are shown in table 1.

Some of the uncovered plots were cultivated 4 inches deep once or twice a month, and others were kept clean of weed growth by cutting the weeds at the surface of the soil weekly in such a way as not to disturb the soil. On May 7, after the paper mulch had been placed on the soil, moisture samples were taken by 1 -foot depths. Between May 11 and 14, just after the soil sampling had been completed, there was a rainfall of 1.14 inches. Although after the rain an occasional pool of water was found on the nonperforated paper, no damage was done to any of the paper mulches other than that the flaps in the perforated papers remained open for the remainder of the season.

Soil Moisture Changes During 1925 Season.-Moisture determinations were made in all of the plots on May 7 and 22, July .6, August 10, 
September 10 , and October 8 . The samples were dried at $212^{\circ} \mathrm{F}$ to constant weight, and the percentage of moisture calculated on oven-dry basis. An additional rain of 0.37 inches fell on May 18 to 20. On May 7 the moisture content of the surface foot of soil in each plot was approximately 16 per cent. Owing to the different treatments which the various plots received, the increase in moisture on May 22 was not uniform in all of the plots. The increase in moisture content of the surface foot of soil on May 22 over that of May 7 for the various plots is shown in table 1. In general, the greatest increases in moisture content occurred in the plots which had been covered with perforated

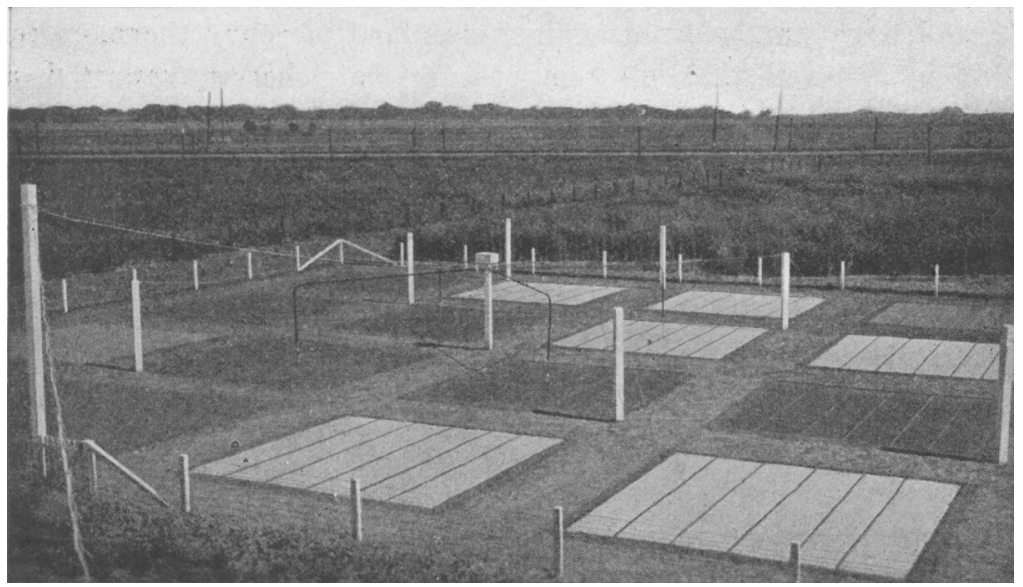

Fig. 1. Paper mulch plots in 1925 season. Various colored papers were used; no crop was grown.

paper mulch. The perforations had permitted the rain water to enter the soil, but the shading effect of the paper had retarded evaporation. Where no paper mulch had been used, a considerable portion of the rain was lost by direct evaporation to the air. Where nonperforated paper was used, moisture entered the soil through the small openings made by the staples which held down the battens.

Plot 13, mulched with Malthine Building Paper, black side up, showed a smaller increase of moisture in the surface foot than in any other paper-mulched plot. This plot contained a heavy growth of morning-glory.

Owing to rain, there was an average increase of about 2 per cent of the oven-dry weight of soil in the moisture content of the second foot in all of the plots between May 7 and May 22. There was also an average increase of about 1 per cent in the moisture content of the 
third foot, while below the third foot, there was no increase in moisture during May.

Table 1 gives the percentage of the original moisture lost from the surface foot of soil between May 22 and October 8, 1925. In the areas not covered with paper the greatest loss of moisture occurred in plots 4 and 8 , where the weeds had been cut at the surface of the soil

TABLE 1

Moisture Changes in Surface Foot of Soll During 1925 Season

\begin{tabular}{|c|c|c|c|c|}
\hline Plot No. & Surface treatment* & $\begin{array}{c}\text { Moisture } \\
\text { increase, } \\
\text { from May } 7 \\
\text { to May } 22 \dagger\end{array}$ & $\begin{array}{c}\text { Loss of } \\
\text { original } \\
\text { moisture } \\
\text { May } 22, \text { to } \\
\text { October } 8 \ddagger\end{array}$ & $\begin{array}{c}\text { Moisture } \\
\text { present } \\
\text { October } 8 \\
\text { based on } \\
\text { moisture } \\
\text { equivalent9 }\end{array}$ \\
\hline & & per cent & per cent & per ccnt \\
\hline $\begin{array}{l}4,8 \\
3,7\end{array}$ & Unmulched plots, cultivated once a month...................... & $\begin{array}{l}0.90 \\
3.51\end{array}$ & 52.29 & 43 \\
\hline 12,16 & Unmulched plots, cultivated twice a month...................... & 2.48 & 51.92 & 46 \\
\hline 13 & $\begin{array}{l}\text { Malthine Building Paper, nonperforated, black side } \\
\text { up, white side underneath }\end{array}$ & 3.60 & 56.18 & 44 \\
\hline 11 & $\begin{array}{l}\text { Pabco Thermo-Gen, nonperforated, black on both } \\
\text { sides }\end{array}$ & 5.27 & 29.01 & 79 \\
\hline 6 & $\begin{array}{l}\text { Pabco Thermo-Gen No. 214, perforated, large triangu- } \\
\text { lar perforations, black on both sides }\end{array}$ & 6.41 & 56.61 & 46 \\
\hline 5 & $\begin{array}{l}\text { Pabco Thermo-Gen No. 214, small round holes, black } \\
\text { on both sides }\end{array}$ & 7.51 & 56.17 & 51 \\
\hline 1 & 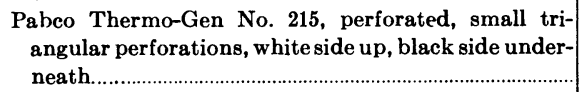 & 4.93 & 50.19 & 49 \\
\hline 9 & $\begin{array}{l}\text { Malthine Building Paper, nonperforated, white side } \\
\text { up, black side underneath }\end{array}$ & 5.38 & 51.52 & 51 \\
\hline 14,15 & Mulch paper plain, nonperforated, gray on both sides & 4.24 & 45.72 & 54 \\
\hline 2,10 & 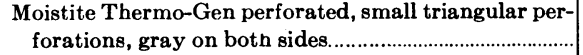 & 4.32 & 47.71 & 54 \\
\hline
\end{tabular}

* Paper on plots 1, 5, 6, 9, 11, and 13 were supplied by the Paraffine Company, Inc., and that on plots $2,10,14$, and 15 by the Zellerbach Paper Company.

$\dagger$ Calculated as per cent of oven-dry weight of soil.

$\ddagger$ The amount of soil moisture present on May 22 was given a value of 100 per cent.

I The moisture equivalent was given a value of 100 per cent. These figures are therefore ratios of moisture present to moisture equivalent.

weekly, but the soil had not been cultivated. The weeds came up through cracks in the uncultivated soil and as the season advanced, the cracks became numerous and deeper. At the time of the last sampling in October, the cracks in these plots averaged 12 inches deep and $1 / 8$ inch wide. The least loss of moisture was in plot 11, which was covered with Pabco Thermo-Gen paper mulch, nonperforated. Although in all of these studies the surface foot of soil has been used in determining moisture changes, it has been shown by later experiments that under the conditions existing here, the conservation of moisture by paper mulches is confined to the surface 4 inches. In 
general, it ean be seen that where the perforated papers were used there was a greater loss of moisture, probably attributable to the circulation of air through the perforations. When the perforations were of the 'hole' type there was of course a greater opportunity for circulation of air than where the perforations were of the 'slit' type, because in the latter the small flaps would partially close the openings.

The moisture losses occurring between May 22 and October 8, in depths beyond the first foot, showed no appreciable differences in the various plots. In the second foot there was an average loss of the original moisture of about 25 per cent, in the third foot approximately 10 per cent, with lesser amounts in the fourth, fifth, and sixth foot. Where the subsoil from 3 feet to 6 feet was of a fairly uniform fine sandy loam there was slightly less moisture present on October 8 than on May 22. The changing moisture content of the soil at depths beyond the first foot is due largely to soil-moisture movement in the vapor phase, and not primarily to capillary movement. Data bearing on this point will be presented later.

Weed Growth During 1925 Season.-In plot 13, which was covered with Malthine Building Paper, difficulty was experienced with morning-glory, which continued to grow under the paper. This weed was more prevalent in this area and in the adjoining paths than elsewhere in the area under experiment. On May 17, an entire strip (36 inches wide) of paper in plot 13 had pulled loose from the battens. The weeds under the torn strip were, on the average, 2 feet apart in groups of four to five plants; they did not come through the paper, but the growth was sufficient to raise the paper, pulling it loose from the battens and wire staples. The weeds were removed and the paper replaced, the torn places being covered with additional strips of the same kind of paper.

The weeds on the other plots were largely amaranth. In plot 5, covered with Pabco Thermo-Gen No. 214, perforated and having small round holes, there were more weeds than on plot 6, covered with Pabco Thermo-Gen No. 214, perforated and having large triangular slits. Where the nonperforated papers were used, weeds came up through the holes made by the staples which held down the redwood battens. Some weeds were present in all of the plots. Those on the unmulched plots were hand-pulled regularly or destroyed by cultivation with a hoe as previously indicated. After the end of July relatively few weeds appeared on any of the plots.

Moisture-Equivalent Determinations in 1925.-Whenever soil samples were obtained they were mixed and divided into two portions, one for soil-moisture determinations and the other for moisture- 
equivalent determinations. The moisture equivalent was determined by using 30 -gram samples of soils, ${ }^{(16)}$ the average result for the surface 3 feet being about 20 per cent, and that of the second 3 feet about 16 per cent.

Harding ${ }^{(5)}$ and Veihmeyer ${ }^{(16)}$ have shown that there is a fairly close relation between the moisture equivalent and the field moisture retained after an irrigation.

The percentage of moisture multiplied by one hundred and divided by the moisture equivalent is designated as percentage of moisture equivalent in table 1. It will be seen that the smallest loss of moisture was in plot 11, which retained moisture to the extent of 79 per cent of the moisture equivalent, and the greatest loss was in plots 4 and 8, which retained moisture to only 29 per cent of the moisture equivalent. In the other plots the amount of moisture present on October 8 , based on the moisture equivalent, ranged from 43 per cent to 54 per cent. A comparison of the moisture equivalents of the surface foot of all the plots was made on each of the six sampling dates between May 7, 1925, and October 8, 1925, and at each date the interpretation was practically the same as given above for October 8 .

Soil Temperatures in 1925.-During the period May 5, 1925, to October 1, 1925, the temperature of each of the sixteen resistance thermometers was recorded every 15 minutes day and night, and nearly 230,000 records were obtained during this period. In order to obtain a comparison of the effects of the various surface treatments on the soil temperatures, the data obtained in a 24 -hour period has been segregated into day temperatures (sunrise to sunset) and night temperatures (sunset to sunrise), and the average temperatures for each day and night period during these 149 days has been calculated. In a previous paper, ${ }^{(14)}$ the importance of considering the day and night temperatures separately was stressed.

Photosynthesis and transpiration in general proceed at a greater rate during sunlight than during darkness. There is less evaporation from soils at night than during the day, and according to Kincer ${ }^{(8)}$ rain falling at night has less tendency to create a crust on cultivated areas than if it falls during the daytime. From records of the elongation of leaves in the date-palm, Mason' ${ }^{(10)}$ results indicate this to be most rapid at night.

Soil temperatures were obtained from plots $6,7,10,11$, and 15, the surface treatments of which are shown in table 1. At a depth of 3 inches, during the first four weeks, the soil in plot 11 under the Pabco Thermo-Gen nonperforated paper averaged, during the day, $5.7^{\circ} \mathrm{F}$ warmer than in plot 7 , where the soil was cultivated once a 
month. The next highest day temperature during this 4-week period was in plot 6 , where the surface was covered with Pabco Thermo-Gen No. 214 perforated black paper. The next in order was the cultivated plot, No. 7 , followed by plot 15 , covered with gray, nonperforated paper. Finally, the lowest average temperature for the first 4 weeks was in plot 10, where the surface was covered with Moistite, a gray perforated paper. During the entire period of 149 days, the black nonperforated paper produced the highest average day and night temperature at a depth of 3 inches, the gray perforated paper produced the lowest temperature, and the other papers were in the same order as during the first 4 weeks.

In order to segregate the temperature data and study the rate of heat movement to given depths in the various plots, several selected weekly periods were chosen as follows: May 5-12, June 9-16, June 23-30, July 14-21, and August 11-18. Continuous air temperatures were obtained by use of a thermograph in the Standard United States Weather Bureau shelter house at the northeast corner of the experimental area.

The period of May 5-12 was partly cloudy with the wind varying from north to southwest but with a preponderance of southwest winds. The second period, June 9-16, was generally clear with slight north winds. The third period, June $23-30$, was generally clear with winds varying from north to southwest. The fourth period, July 14-21, was partly cloudy to clear with 3 days of calms and 4 days of light southwest wind. The last period, August 11-18, was generally clear with 2 days of calm, 1 of north wind, and the remainder with moderate to strong southwest winds.

The maximum of any one soil thermometer at the 3-inch depth did not occur consistently later or earlier than that of any other at the same depth. On the average the maximum temperatures at a depth of 3 inches occurred about 2 hours after the maximum air temperatures. The soil maximum temperatures, although not varying with respect to the time of occurrence, did vary in intensity, which is consistent with the results previously reported.

The average minimum temperatures at the 3-inch depth in the five plots during these 5 weeks occurred not later than 2 hours after the average minimum air temperatures.

The maximum temperatures at the 12-inch depth in the various plots occurred on the average of 7 hours and 45 minutes after the maximum air temperatures. In general, these maxima occurred within 45 minutes of each other. 


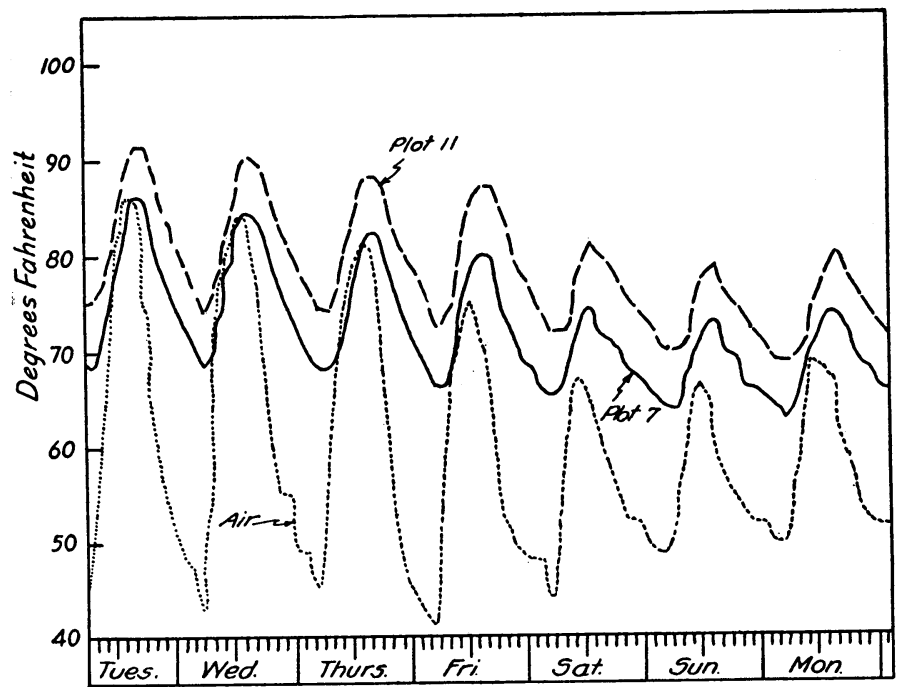

Fig. 2. Temperatures at 3-inch depth in mulched and unmulched plots and of air. Week of May 5-12, 1925. Plot 11-Covered with Pabco Thermo-Gen nonperforated, black on both sides. Plot 7-Unmulched, cultivated once a month.

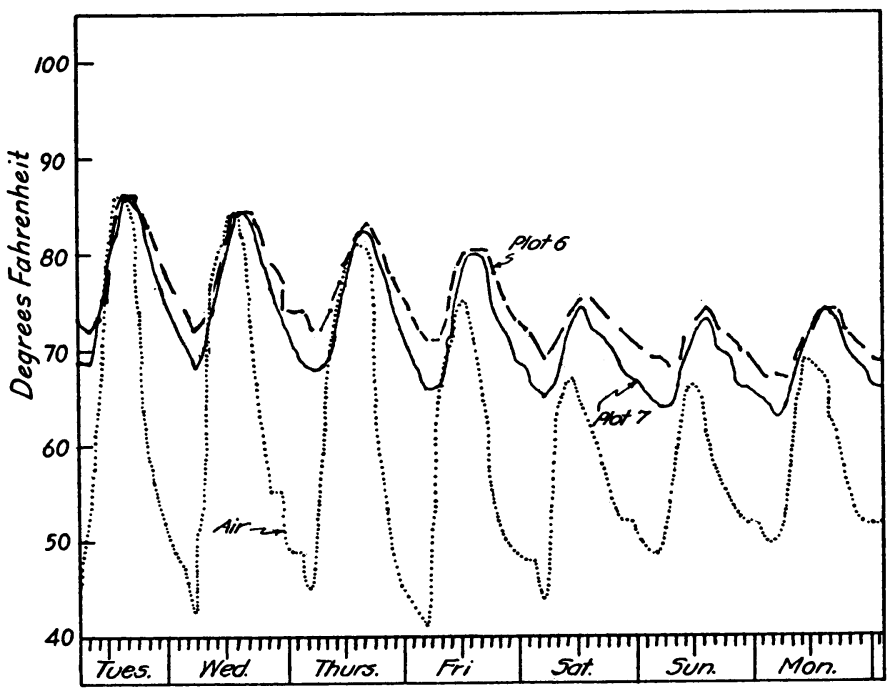

Fig. 3. Temperatures at 3-inch depth in mulched and unmulehed plots and of air. Week of May 5-12, 1925. Plot 6-Covered with Pabco Thermo-Gen No. 214, perforated, large triangular slits, black on both sides. Plot 7-Unmulched, eultivated once a month. 


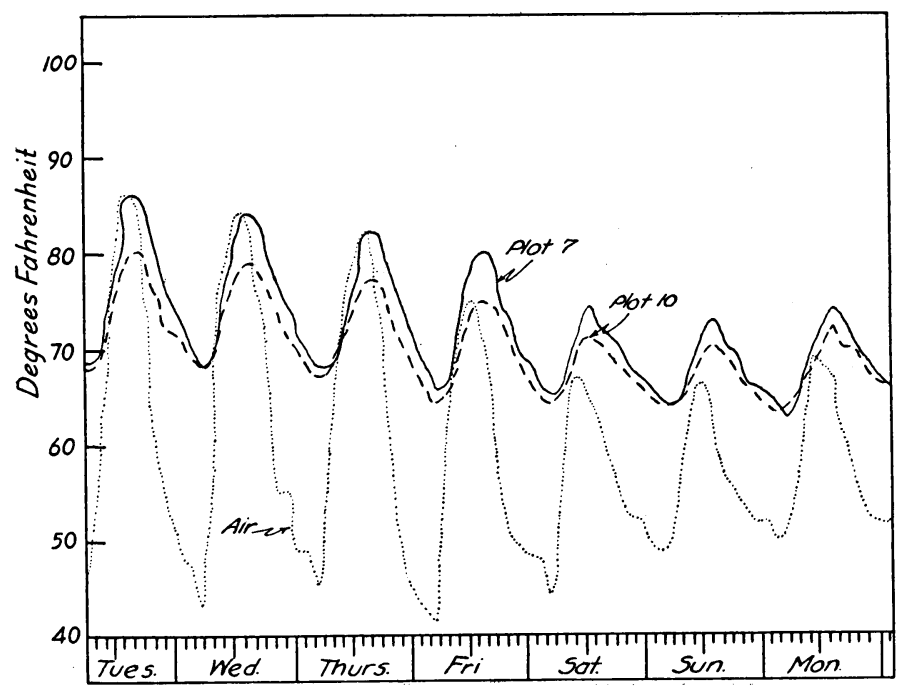

Fig. 4. Temperatures at 3-inch depth in mulched and unmulehed plots and of air. Week of May 5-12, 1925. Plot 10-Covered with Moistite Thermo-Gen perforated, small triangular slits, gray on both sides. Plot 7-Unmulched, cultivated once a month.

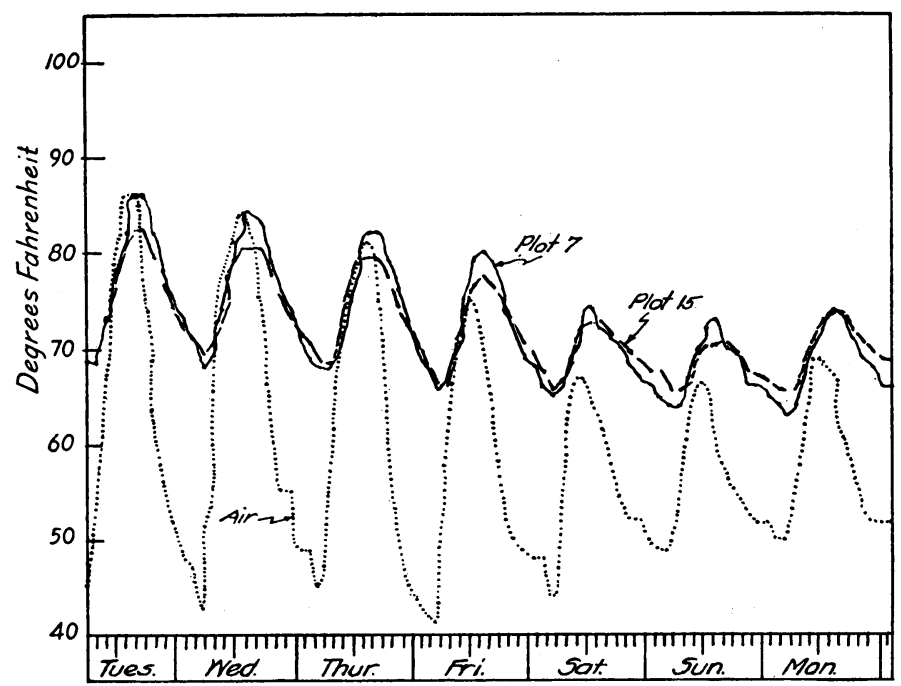

Fig. 5. Temperatures at 3-inch depth in mulched and unmulched plots and of air. Week of May 5-12, 1925. Plot 15-Covered with mulch paper plain, nonperforated, gray on both sides. Plot 7-Unmulehed, cultivated once a month. 


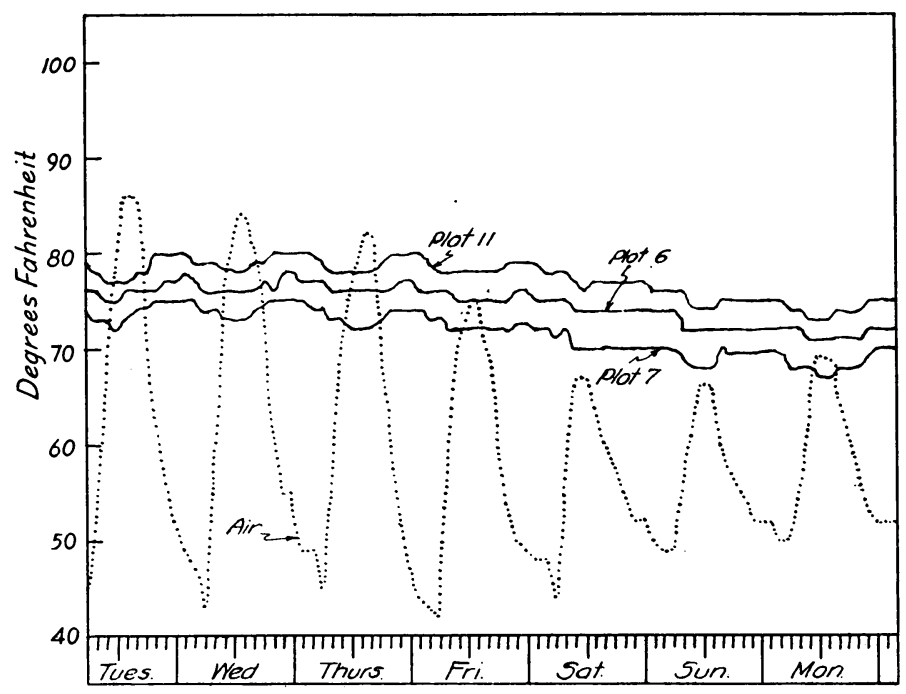

Fig. 6. Temperatures at 12-inch depth in mulched and unmulched plots and of air. Week of May 5-12, 1925. Plot 11-Covered with Pabco Thermo-Gen nonperforated, black on both sides. Plot 6-Covered with Pabco Thermo-Gen No. 214 perforated, large triangular slits, black on both sides. Plot 7-Unmulched, cultivated once a month.

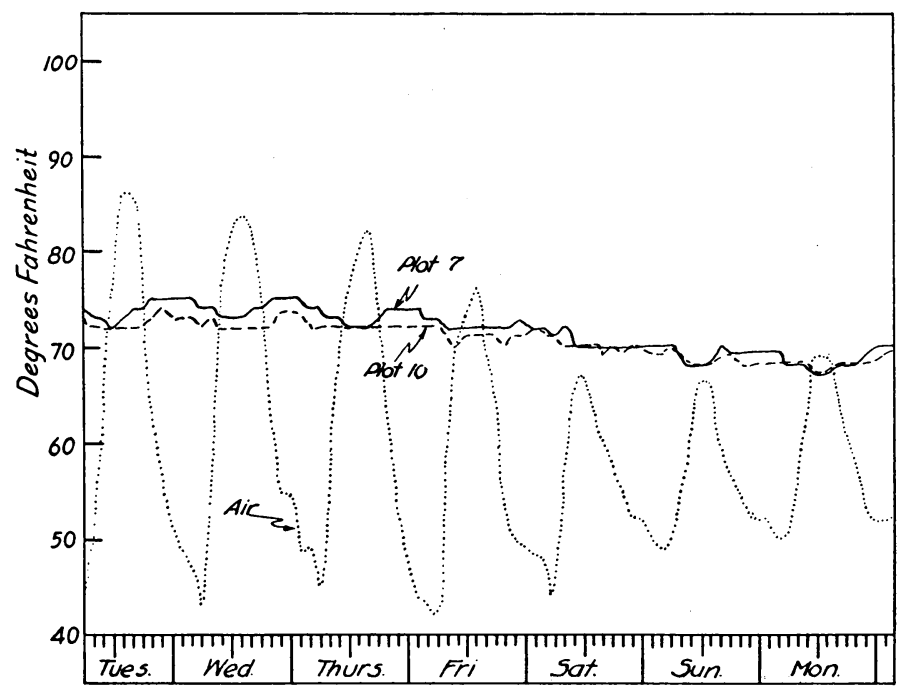

Fig. 7. Temperatures at 12-inch depth in mulched and unmulched plots and of air. Week of May 5-12, 1925. Plot 10-Covered with Moistite Thermo-Gen perforated, small triangular slits, gray on both sides. Plot 7-Unmulched, cultivated once a month. 


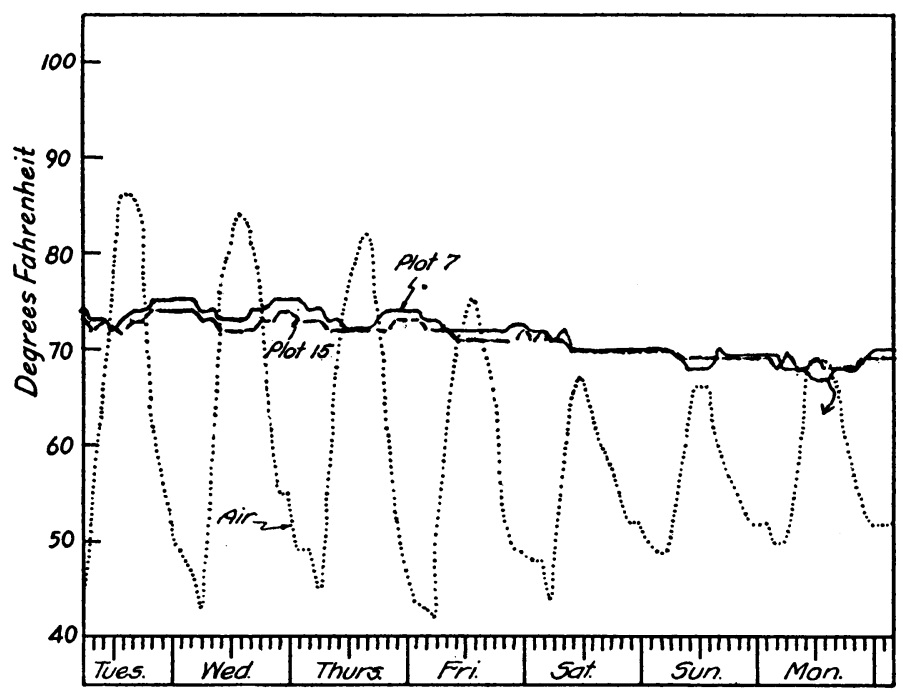

Fig. 8. Temperatures at 12 inch depth in mulched and unmulched plots and of air. Week of May 5-12, 1925. Plot 15-Covered with mulch paper plain, nonperforated, gray on both sides. Plot 7-Unmulehed, cultivated once a month.

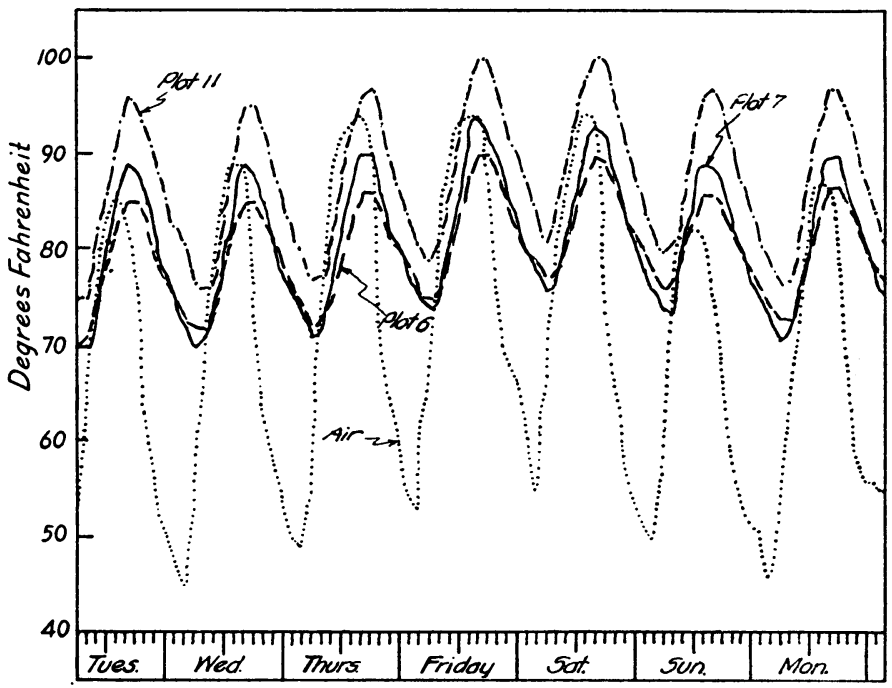

Fig. 9. Temperatures at 3-inch depth in mulched and unmulched plots and of air. Week of June 9-16, 1925. Plot 11-Covered with Pabco Thermo-Gen, nonperforated, black on both sides. Plot 6-Covered with Pabco Thermo-Gen No. 214, perforated, large triangular slits, black on both sides. Plot 7-Unmulehed cultivated once a month. 


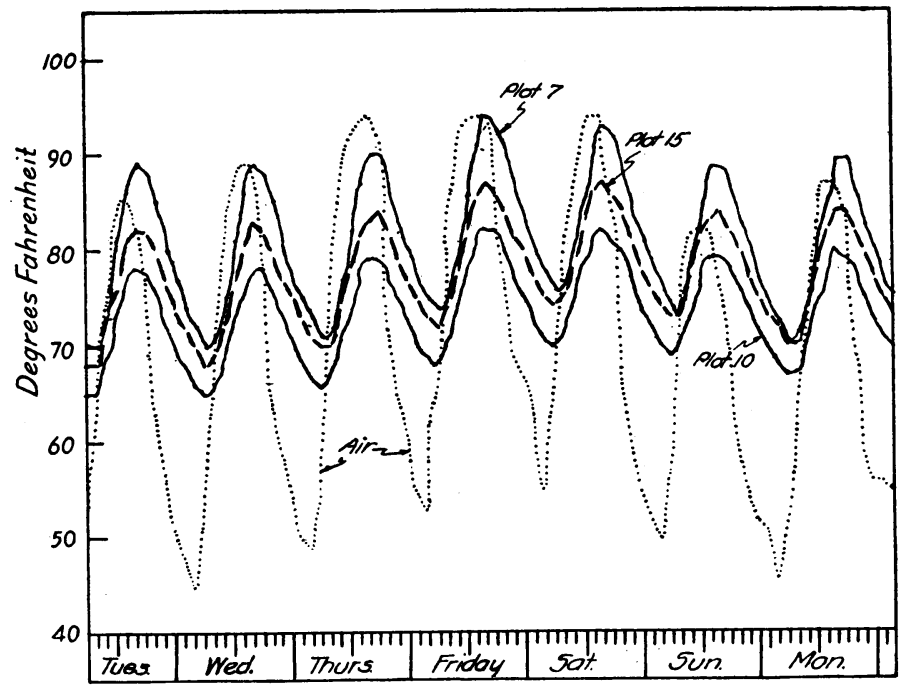

Fig. 10. Temperatures at 3-inch depth in mulched and unmulched plots and of air. Week of June 9-16, 1925. Plot 10-Covered with Moistite Thermo-Gen, perforated, small triangular slits, gray on both sides. Plot 15-Covered with mulch paper plain, nonperforated, gray on both sides. Plot 7-Unmulched, cultivated once a month.

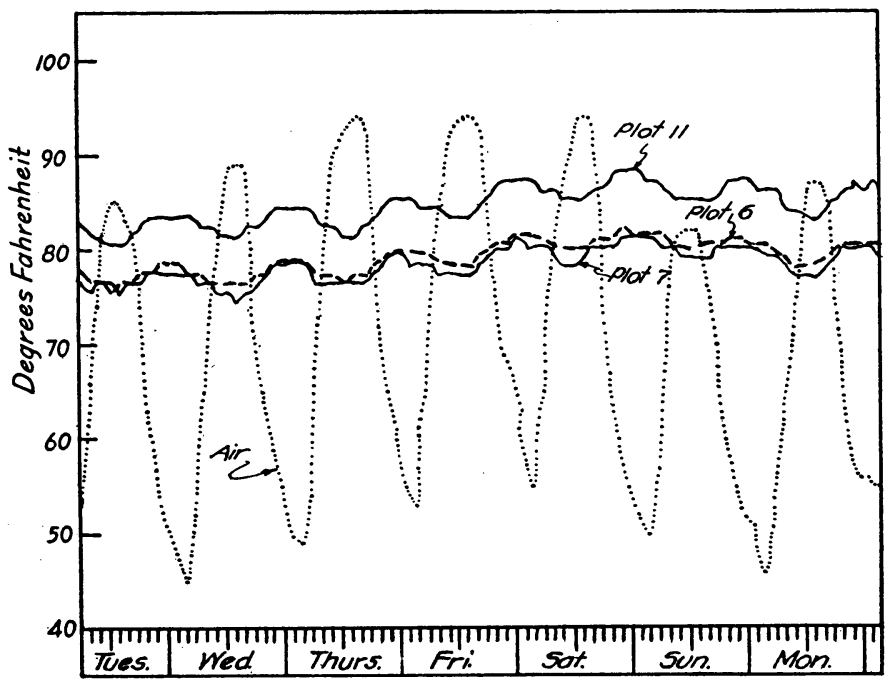

Fig. 11. Temperatures at 12-inch depth in mulched and unmulched plots and of air. Week of June 9-16, 1925. Plot 11-Covered with Pabco Thermo-Gen, nonperforated, black on both sides. Plot 6-Covered with Pabco Thermo-Gen No. 214, perforated, large triangular slits, black on both sides. Plot 7-Unmulched, cultivated once a month. 


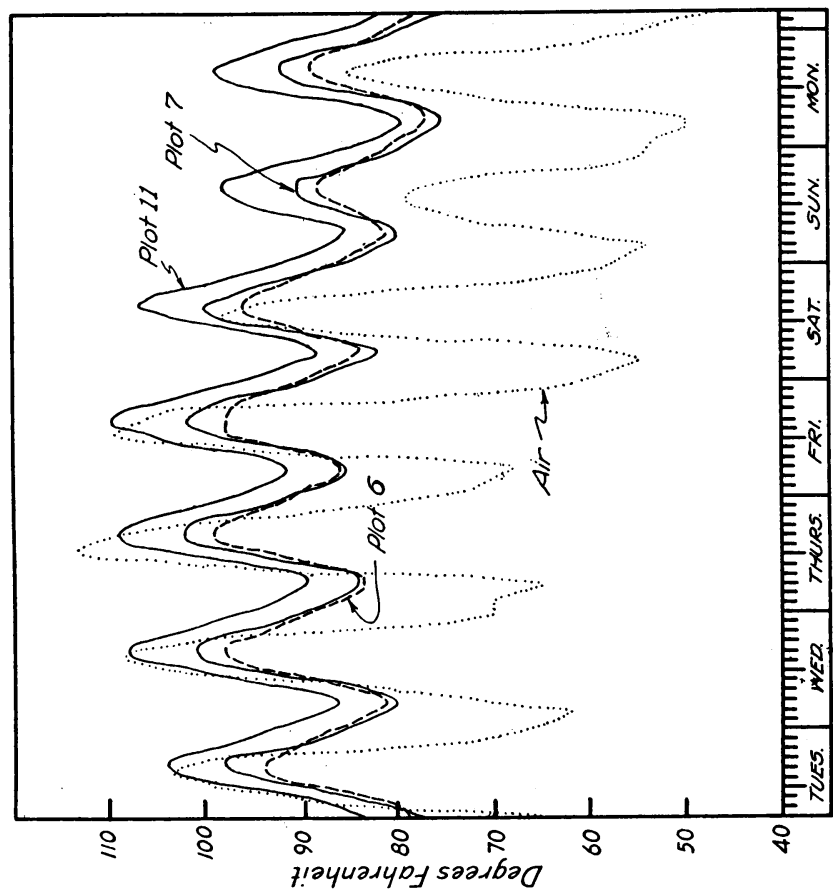

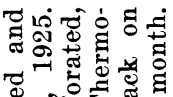

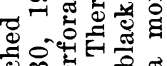
政

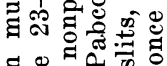
ㅖㅕㄹ

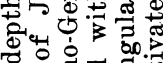
열

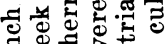
के

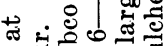
कै 5 击 密萨要

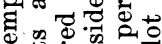
= मी०

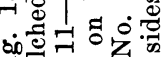

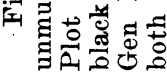

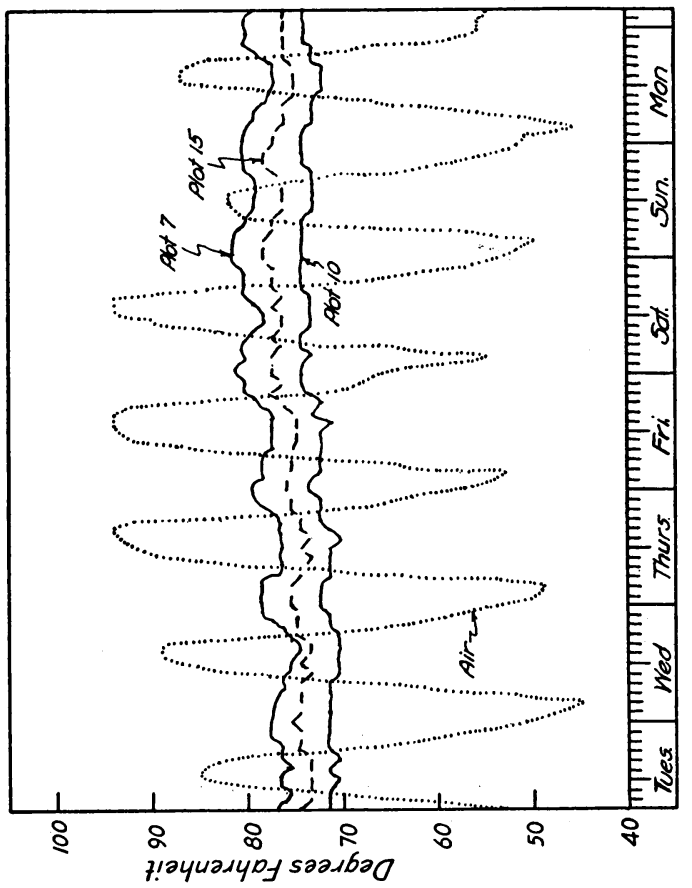

ซึ่ง

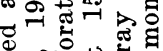
过 苛 घ

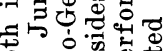

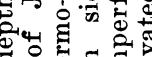
क्ष

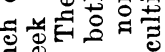
जิ 7 .

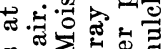
क प्त

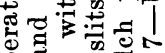
急

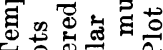

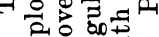
ค

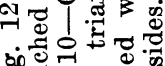
证

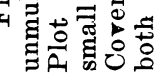




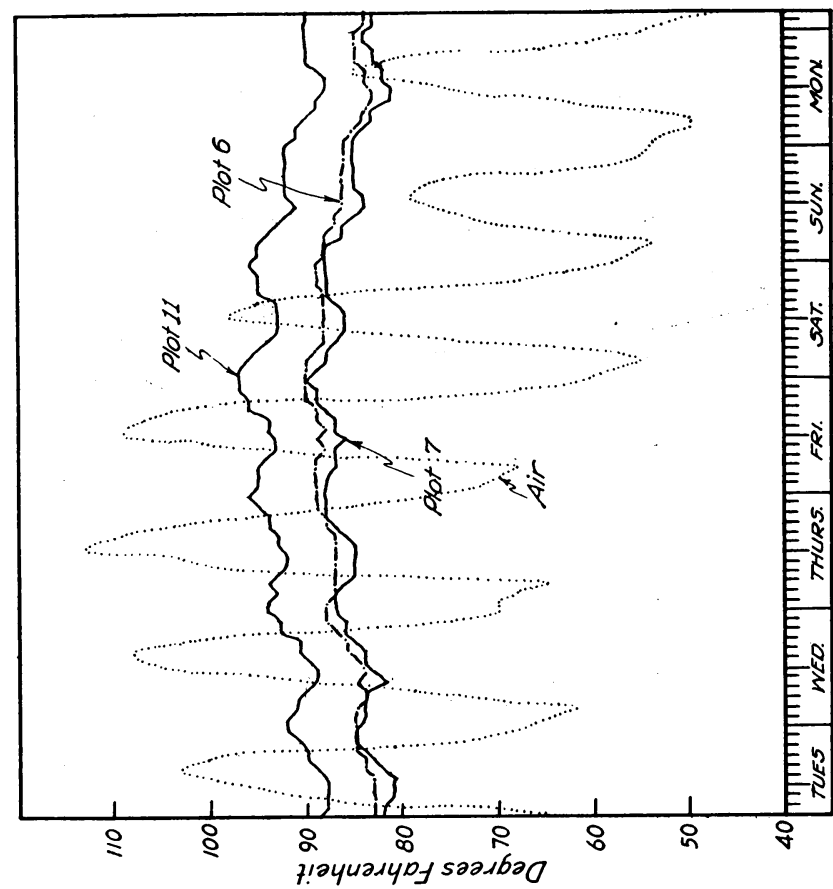

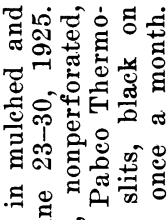

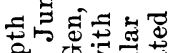

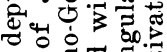

두월

\&

ง่ं

๘. \&

क त ज है

प 4 की

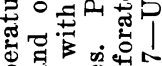

कृ

员舟

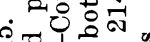

过

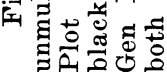

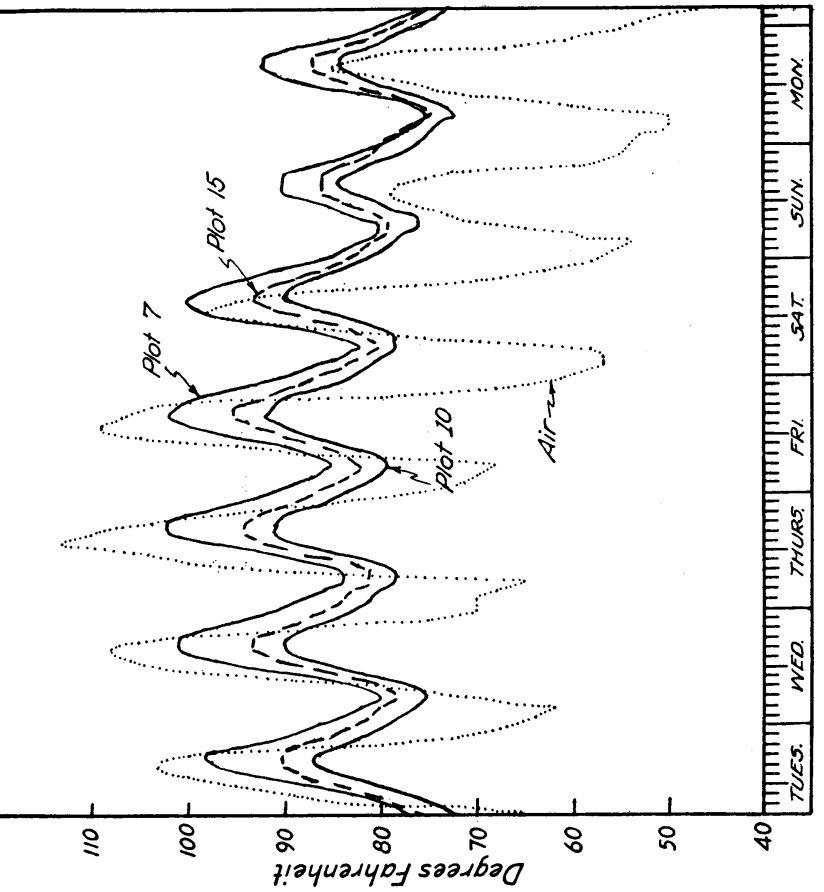

ซึ่

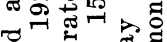

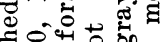

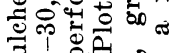

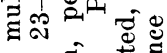
ઘ

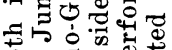
क्ष है

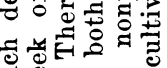
คे 范 क

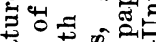

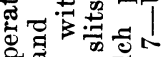

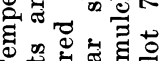

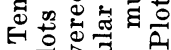

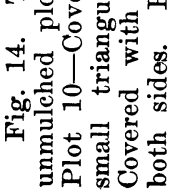




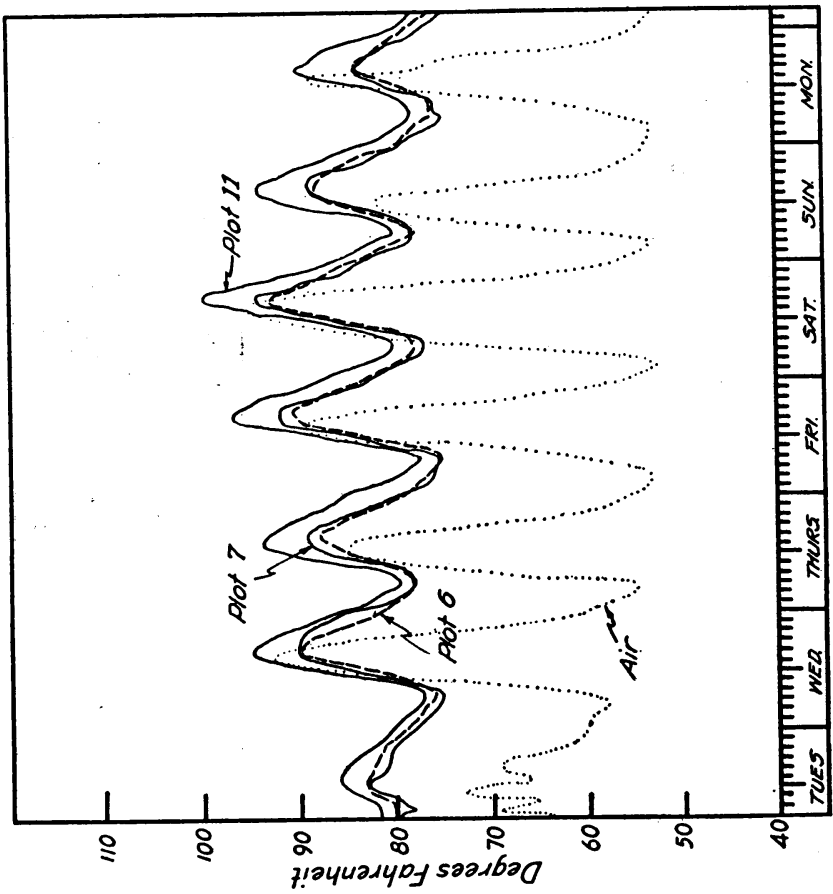

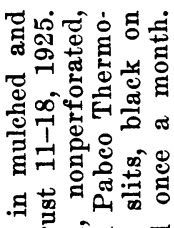

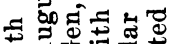

क्य

떵 है

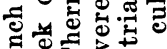

ஸें ठ요

+

के नै सेत्र है

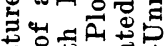

可的要

궁

o 0

से

. ति 苛

궁

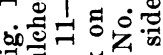

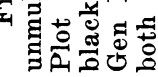

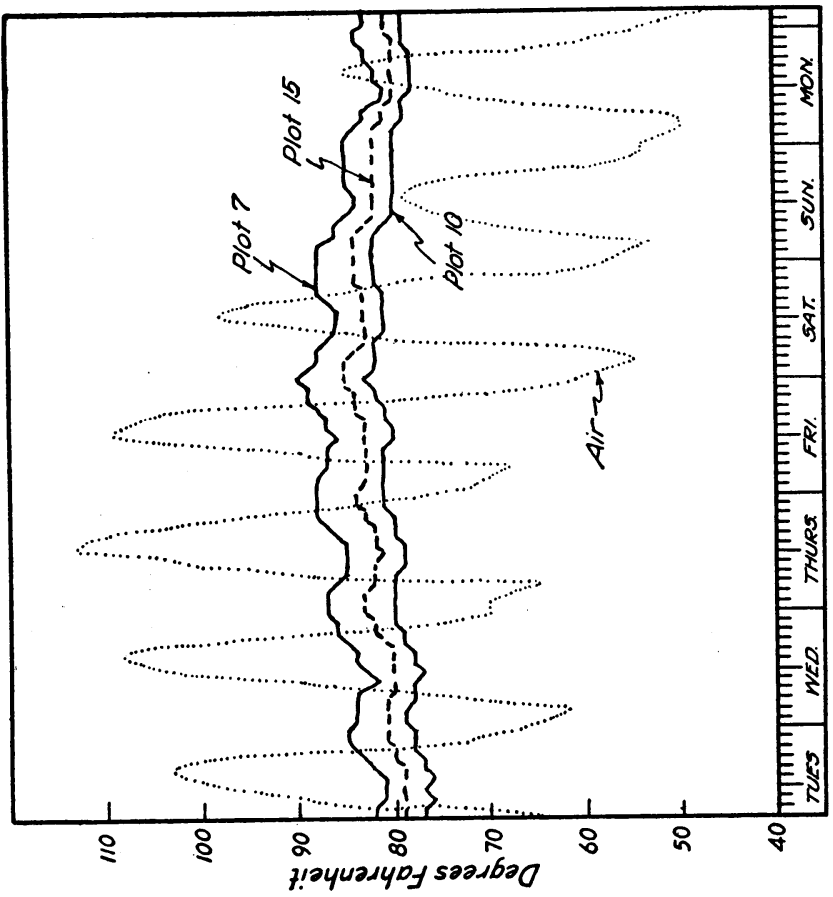

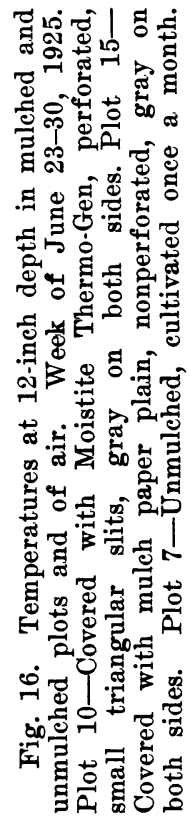




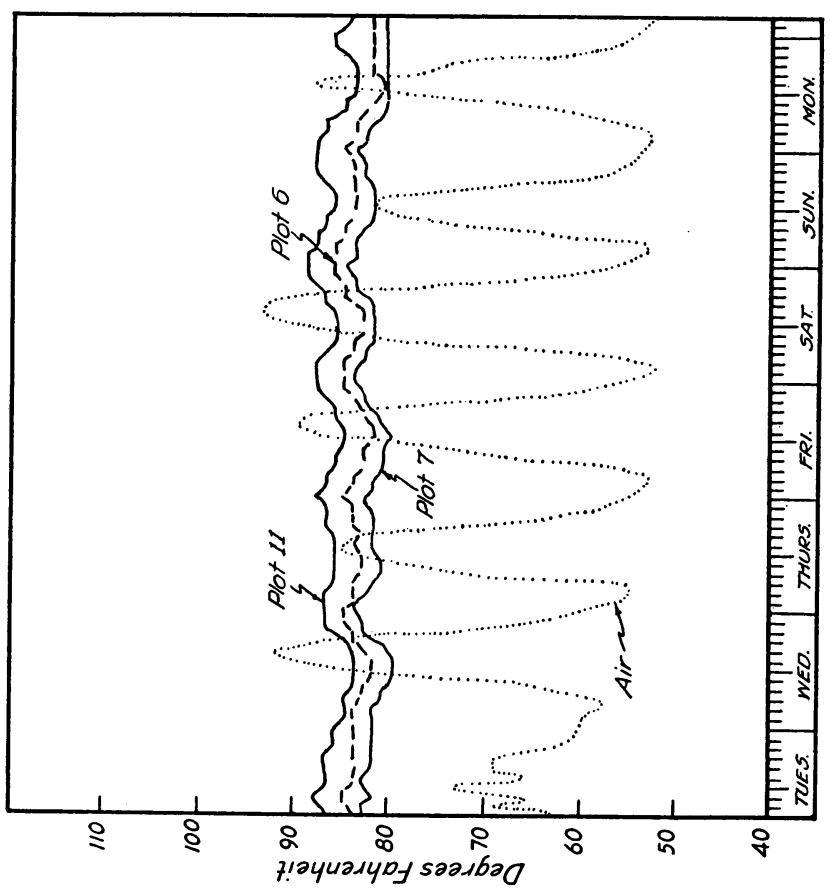

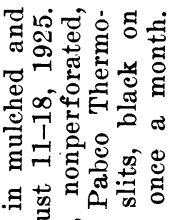

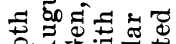
क्षय

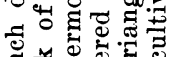
능 งें ๘ क ఫี

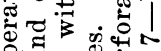
क्ष

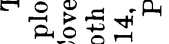
केत्ठ

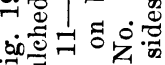

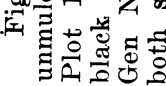
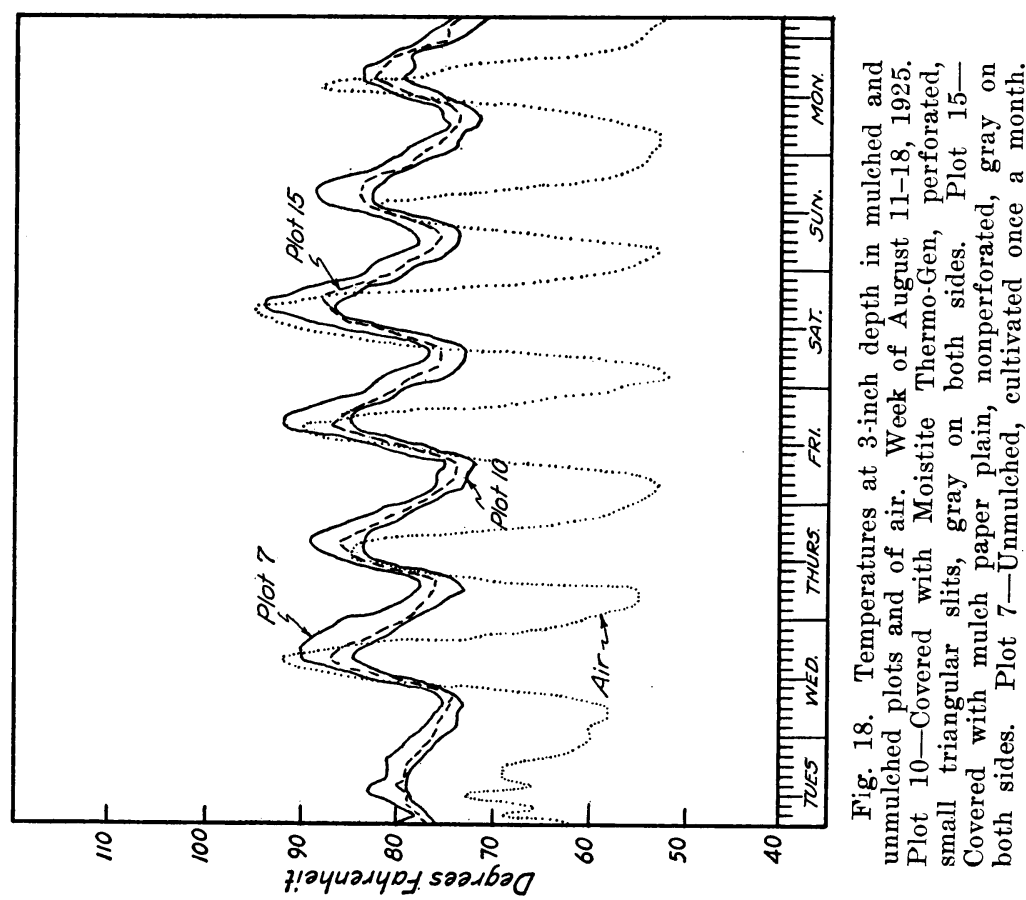
The minimum temperatures at the 12 -inch depth during these 5 weeks, occurred on the average of 5 hours and 5 minutes after the air minimum. The difference in time of occurrence of the minimum temperature in the different plots at the 12-inch depth does not appear to be significant.

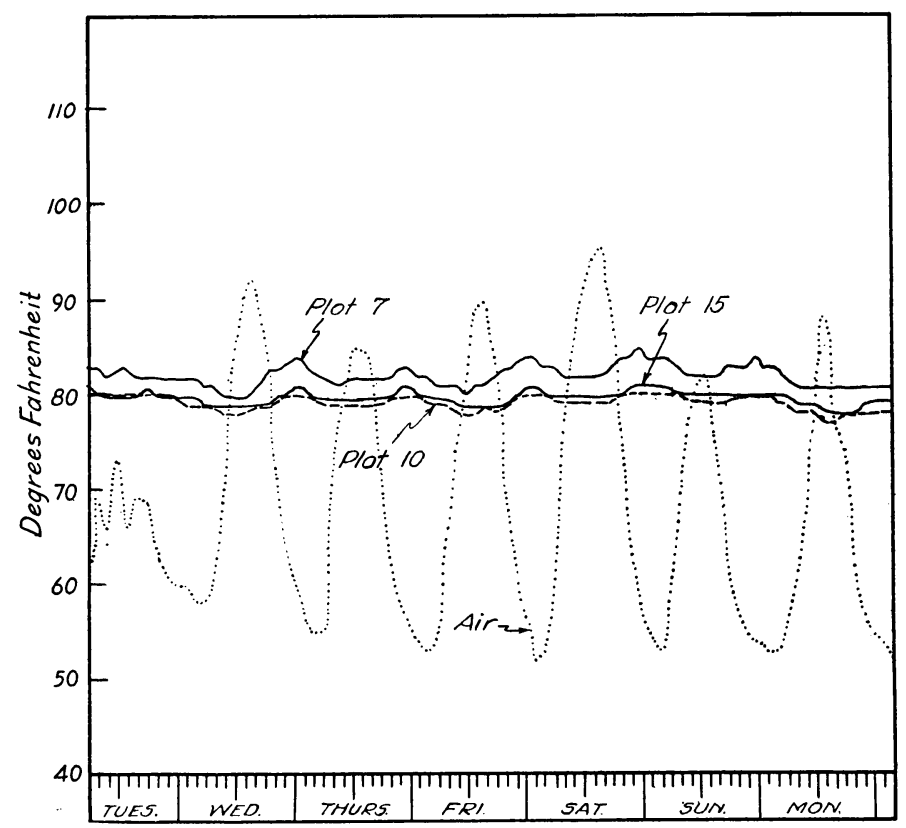

Fig. 20. Temperatures at 12-inch depth in mulched and unmulched plots and of air. Week of August 11-18, 1925. Plot 10-Covered with Moistite ThermoGen, perforated, small triangular slits, gray on both sides. Plot 15-Covered with mulch paper plain, nonperforated, gray on both sides. Plot 7-Unmulehed, cultivated once a month.

In figures 2 to 20 the temperature changes occuring at the 3 -inch and 12-inch depths in the various areas are shown for 4 of the 5 selected weeks. Those for the period July 14-21 have previously been reported. ${ }^{(13)}$

Considering the temperature data for these 5 weeks when the character of the sky and wind direction varied, either by individual weeks or all together, or taking the averages by weeks for 147 days, the effect of the various surface treatments is always in the same order. The average day and night temperature for the 21 weeks, May 5 to September 30,1925, at a depth of 3 inches was highest in the plot covered with black nonperforated paper, where it was warmer during 
both day and night than in the cultivated plot. The area covered with black perforated paper had practically the same day temperatures but was slightly warmer at night than the cultivated plot. Under the gray perforated and nonperforated papers it was colder during the day and night than in the cultivated plot (fig. 21).

At the 12-inch depth the average temperatures for the 21 weeks were higher during the day and night, in the area covered with black nonperforated paper, and under the black perforated paper it was
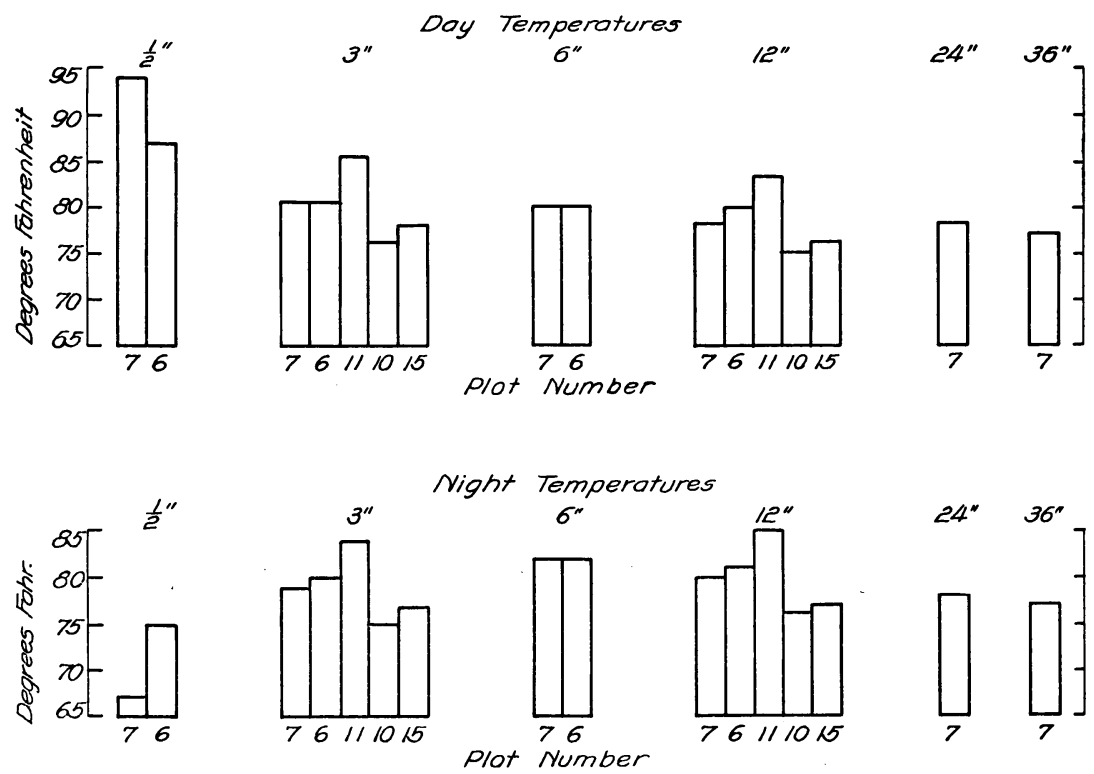

Fig. 21. Average day and night soil temperatures at various depths. May 5September 30, 1925. Plot 6-Covered with Pabco Thermo-Gen No. 214, perforated, large triangular slits, black on both sides. Plot 7-Unmulched, cultivated once a month. Plot 10-Covered with Moistite Thermo-Gen, perforated, small triangular slits, gray on both sides. Plot 11-Covered with Pabco Thermo-Gen, nonperforated, black on both sides. Plot 15-Covered with mulch paper, plain, nonperforated, gray on both sides.

only slightly warmer during the day and night than in the cultivated plot. The areas covered with gray perforated and nonperforated papers were colder during the day and night than the cultivated plot.

In the cultivated plot, at a depth of 24 inches, the average day temperature was $78.4^{\circ} \mathrm{F}$. This was higher than the average day temperature at a depth of 12 inches in the plots covered with gray perforated or nonperforated papers. The average night temperature at 24 inches in the cultivated plot was $78.2^{\circ}$, and this again was higher 
than the average night temperature at a depth of 12 inches in the plots covered with the gray perforated and nonperforated paper mulches.

The greatest depth where soil temperatures were obtained was 36 inches and this only in the cultivated plot, where the average day temperature of $76.8^{\circ} \mathrm{F}$ was slightly higher than the average day temperature at a depth of 12 inches under the gray mulch papers. The average night temperature in the cultivated plot at a depth of 36 inches was $76.9^{\circ}$, which was slightly higher than the average night temperature at a depth of 12 inches in the plot covered with gray perforated paper and practically the same as the average night temperature at a depth of 12 inches in the plot covered with the gray nonperforated paper.

\section{PAPER MULCH TRIALS IN 1926}

As the result of the findings of the previous season, only two types of paper mulch were used in 1926. These two were alike save that one was nonperforated and the other was perforated. The papers were 36 inches wide, asphalt impregnated, and black on both sides. Each roll of both types contained 500 square feet and weighed 45 pounds. Type No. 1, known as Thermo-Gen No. 134, was nonperforated and cost $\$ 1.80$ a roll. Type No. 2, known as Thermo-Gen No. 234, had small triangular perforations and cost $\$ 1.90$ a roll. The perforations in Thermo-Gen No. 234 were cut sharper than in the black perforated paper used in 1925 and consequently there was less air movement through the slits.

In 1926 the flaps on the paper were not disturbed by rain as was the case in 1925. Under these conditions the marked differences found in 1925 between the perforated and nonperforated papers did not occur in 1926. The surface treatments used in 1926 are shown in table 2 . On the plots which were only partially covered with paper mulch, the 3-foot-wide strips were so placed that the crop row was in the center of the paper strips. There was approximately as much bare bround between these strips as was covered by them.

Grain Sorghum Used as the Indicator Crop in 1926.-A grain sorghum (Yolo) was planted in this year. The areas which had not been cultivated or covered with paper mulch in 1925 were spaded 8 inches deep in December. The other areas were loose and mellow after the paper mulches were removed. All of the plots were hoed in February and again in April, 1926, and seeded between April 17 and 20. 
Where the entire plot was covered with paper, a plank was placed on the paper and the seeding was done by working from this plank so as not to break the paper. Small holes were made 8 inches apart in the paper and soil, and the rows were spaced 4 feet apart; the seed of Yolo sorghum was placed 11/4 inches deep with two seeds per hole. On April 29-30, the plants were thinned out so that they were 8 inches apart in the row. Where the seed failed to germinate because of the dryness of the upper inch of soil or because cutworms or squirrels had destroyed the young plants, a second seeding was made. It was only necessary to reseed about 5 per cent of the area.

TABLE 2

Plot Treatments in 1926 Season

\begin{tabular}{|c|c|}
\hline Plot No. & Surface treatment \\
\hline $1,2,6$ & Unmulched, cropped to Yolo grain sorghum. \\
\hline $3,4,8$ & $\begin{array}{l}\text { Partially covered with Thermo-Gen paper mulch No. 234, perforated, black on both } \\
\text { sides; cropped to Yolo grain sorghum. }\end{array}$ \\
\hline 7 & Unmulched, not cropped. \\
\hline $5,9,10$ & $\begin{array}{l}\text { Covered completely with Thermo-Gen paper mulch No. 134, nonperforated, black } \\
\text { on both sides; cropped to Yolo grain sorghum. }\end{array}$ \\
\hline $11,12,16$ & $\begin{array}{l}\text { Covered completely with Thermo-Gen paper mulch No. 234, perforated, black on both } \\
\text { sides; cropped to Yolo grain sorghum. }\end{array}$ \\
\hline $13,14,15$ & $\begin{array}{l}\text { Partially covered with Thermo-Gen paper mulch No. 134, nonperforated, black on } \\
\text { both sides; cropped to Yolo grain sorghum. }\end{array}$ \\
\hline
\end{tabular}

Moisture Determinations in 1926 Season.-In order to obtain information on the moisture distribution in the various cropped plots, soil samples were taken several times during the season from four locations in each plot. It should be remembered that at no time during this experiment has there been any water applied other than rain, but immediately before the seeding, a deep boring showed the soil to be moist to the water table, which at that time was at a depth of 22 feet. The first sampling in 1926 was made on April 1, prior to seeding, and moisture was determined by foot sections to a depth of 6 feet. Owing to rains totaling 5.37 inches between April 4 and April 9, it was necessary to resample on April 15. The third sampling was made on June 4, and the final sampling was made at harvest. The moisture content in the surface foot increased 2.19 per cent of the oven-dry weight of soil on the average between April 1 and April 15. In 1926 as well as in the previous season up to June 1, the immediate surface of the soil was more moist where black nonperforated paper was used than where there was no paper.

On June 4 samples of the surface foot were obtained by 4 -inch layers and the second and third feet by foot layers. Expressing the 
moisture content by foot sections, no marked differences were found on June 4. The averages of the combined three 4-inch sections of the surface foot under the paper mulches ranged from 13.77 per cent to 12.82 per cent of the oven-dry weight of soil; the second foot ranged from 19.44 per cent to 18.85 per cent. When considering only the surface 4 inches however, there was a difference of 3.69 per cent between the maximum and minimum. Up to June 4 the areas on which paper mulches had been placed contained an average of 2.89 per cent more moisture in the surface foot than in the unmulched cropped plots, based on oven-dry weight of soil. At the end of the growing season (September) the plots which had been cropped showed no significant difference in the moisture content of the $0-4$ inch, 4-8 inch, and 8-12 inch sections of the surface foot. The total loss of moisture in the surface foot of the cropped plots during the growing season ranged from 12.58 per cent to 13.10 per cent based on oven-dry weight of the soil.

In the second foot between April 1 and April 15, the moisture content in the cropped plots was increased in all by an average of 1.99 per cent, and at harvest time the losses from all cropped plots were approximately the same, ranging from 11.50 per cent to 13.18 per cent based on oven-dry weight of the soil.

In the third foot the increase in the moisture content between April 1 and April 15 averaged 2.02 per cent, and at harvest the moisture losses from the third foot of the cropped plots ranged from 10.82 per cent to 12.87 per cent based on oven-dry weight of the soil.

Between the first and second sampling in April, the moisture content in the fourth foot increased by an average of 1.76 per cent, and the moisture losses up to harvest time, on the cropped plots, showed a greater range (9.70 per cent to 13.74 per cent based on oven-dry weight of the soil) than occurred in any part of the upper 3 feet of soil. This range in the fourth foot was due to the variation in texture of the soil which occurs at about this point. During the early part of April there was a slight increase in the moisture content of the fifth and sixth foot, and during the growing season the moisture losses were somewhat comparable to those occurring in the fourth. Judging from the condition of the crop, it appears that when the moisture content of the surface three feet of soil is reduced to 11 per cent and that of the 3-6 foot section is reduced to 8 per cent there is no readily available moisture for crops. Consequently, at the time of harvest, all of the readily available moisture had been used from the surface 6 feet of all the planted plots. The crop did not grow as large on the 
unmulched plots as on those where the paper mulch was used, and this would naturally affect the rate at which the soil moisture would be used.

In summarizing the moisture losses by comparing the $0-3$ foot and the 3-6 foot area, it was found that the unmulched cropped areas showed slightly less moisture loss in both sections. The moisture losses in the paper-mulched plots were in close agreement, but it is of interest that the order of the losses was always the same whether these were considered on the basis of 1-foot sections or 3-foot sections of the soil. The areas which were entirely covered with perforated paper had a greater moisture loss than those which were entirely covered

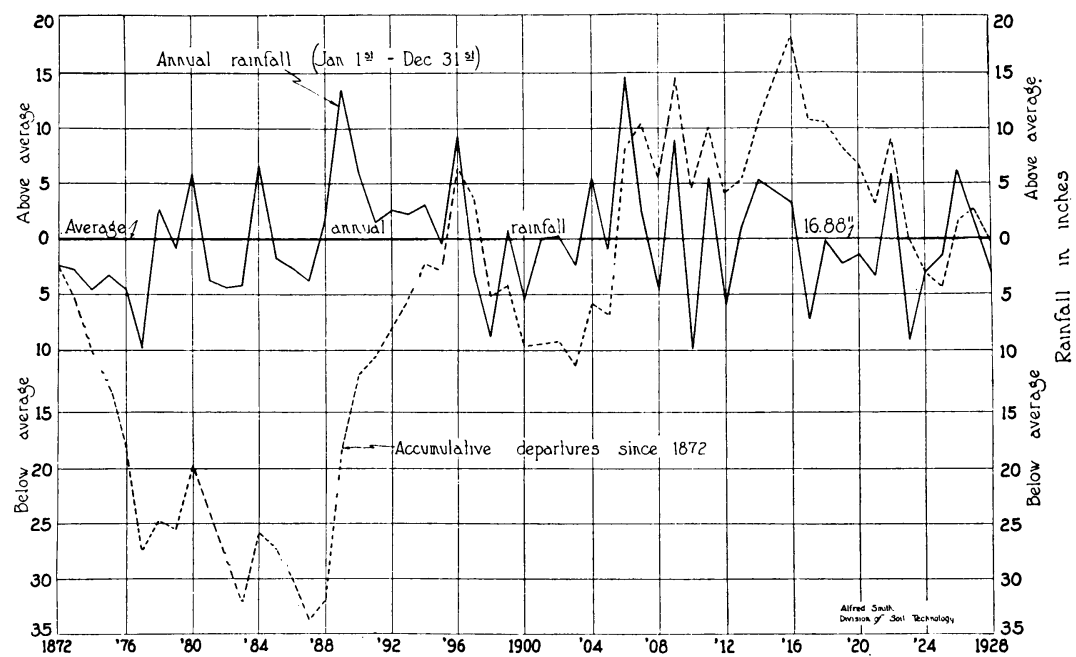

Fig. 22. Rainfall and accumulative departures at Davis, California, 1872 to 1928.

with nonperforated paper. Where the strips of nonperforated paper were used, the moisture losses were greater than where strips of perforated paper were used. In considering moisture changes as the growing season progressed, it is necessary to consider the possible shading effect of the crops during the latter part of the growing season. This is particularly noticeable in the soil-temperature studies discussed later.

A brief analysis of the rainfall records at Davis, California, are of interest at this point. Figure 22 shows the annual rainfall from 1872 to 1928 and the accumulative departures. The average annual rainfall for this period is 16.88 inches. It will be noticed that during the period 1924-1928, during which these experiments were being carried 
was used. In general, from the beginning of the growing season until the tenth week the difference in the cropped plots between the papermulched plots and the unmulched plot decreased because of the shading effect of the crop. The irregularity of the curve for plot 15 is probably due to the fact that at a depth of about $5 \frac{1}{2}$ feet in this area the soil is a sand with a much lower water-holding capacity and the Yolo did not continue to grow as well as in the plots where the texture at that depth was a fine sandy loam. The shading effect of the

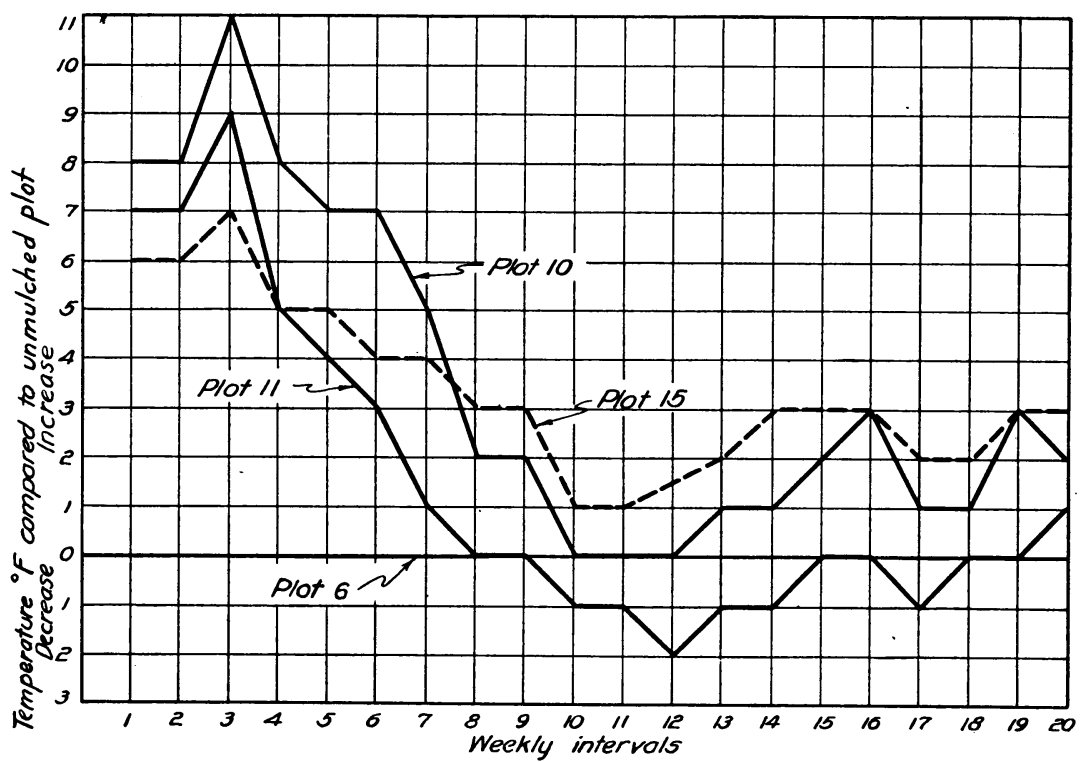

Fig. 24. Effect of paper mulch in the cropped plots at the 3-inch depth during the 1926 season (April 24 to September 2), as shown in the weekly night average temperatures in degrees Fahrenheit, higher or lower than the temperatures of the unmulched plot. Plot 6-Unmulched. Plot 10-Covered completely with Thermo-Gen No. 134, nonperforated. Plot 11-Completely covered with Thermo-Gen No. 234, perforated. Plot 15-Partially covered with ThermoGen No. 134, nonperforated.

Yolo was therefore not as pronounced on plot 15 as on the other plots. The plant roots in all plots extended below 6 feet in depth.

Towards the end of the growing season as the crop matured, the paper-mulched plots were warmer at the 3 -inch depth than earlier in the season when the plants were in the thrifty green condition. In the area completely covered with nonperforated paper, the weekly day and night average temperatures at the 3 -inch depth were in the early part of the season from 8 to $11^{\circ} \mathrm{F}$ higher than in the unmulched cropped plot. In 1926 temperature data indicate, as did those of the 
previous season, that when the paper is perforated the entire width of the strip, the warming effect is not as great as when the paper is not perforated.

Figures 25 and 26 show the difference in the weekly day and night average temperature at a depth of 12 inches in the paper-mulched plots compared to the unmulched cropped plot, the general appearance of these figures being similar to figures 23 and 24 . The weekly

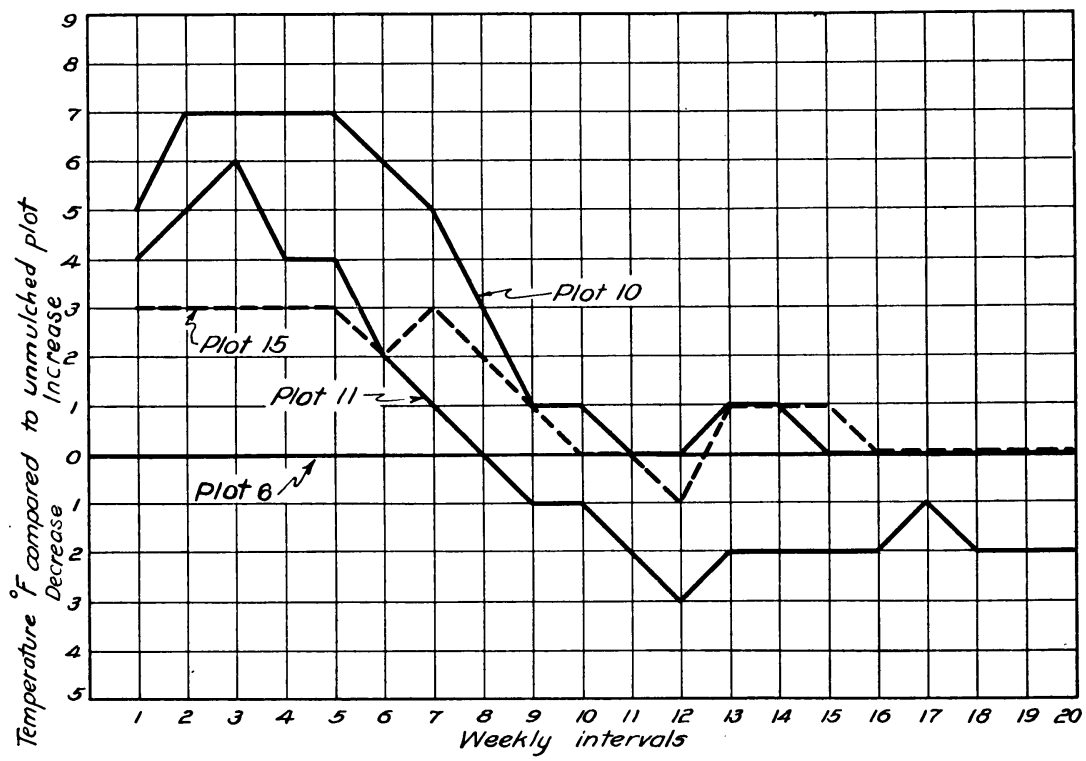

Fig. 25. Effect of paper mulch in the cropped plots at the 12-inch depth during the 1926 season (April 24 to September 2), as shown in the weekly day average temperatures in degrees Fahrenheit, higher or lower than the temperatures of the unmulched plot. Plot 6-Unmulched. Plot 10-Covered completely with Thermo-Gen No. 134, nonperforated. Plot 11-Completely covered with Thermo-Gen No. 234, perforated. Plot 15-Partially covered with Thermo-Gen No. 134, nonperforated.

day and night average temperatures at the 12-inch depth in the area completely covered with the nonperforated paper were sometimes as much as $7^{\circ} \mathrm{F}$ higher than in the unmulched cropped plot.

In general, before the crop had reached the height of 12 inches, the maximum and minimum soil temperatures at a depth of 3 and 12 inches in all the paper-mulched plots, occurred 20 to 40 minutes later than in the unmulched cropped plot. After the crop had attained a growth of over 12 inches in height these temperatures occurred from 12 to 20 minutes earlier in the paper-mulched plots than in the unmulched cropped plot. 
Rate of Crop Growth in 1926.-As previously stated, the Yolo was planted on the various plots between April 17 and April 20, and by April 30 the height of the plants ranged from $13 / 4$ to $2 \frac{1}{2}$ inches. The plots were all weeded on May 15 . In the unmulched plots twice the time was necessary for weeding as in the areas that were partially covered with paper mulch, while on the plots which had been completely covered with paper, no weeding was necessary. By May 25,

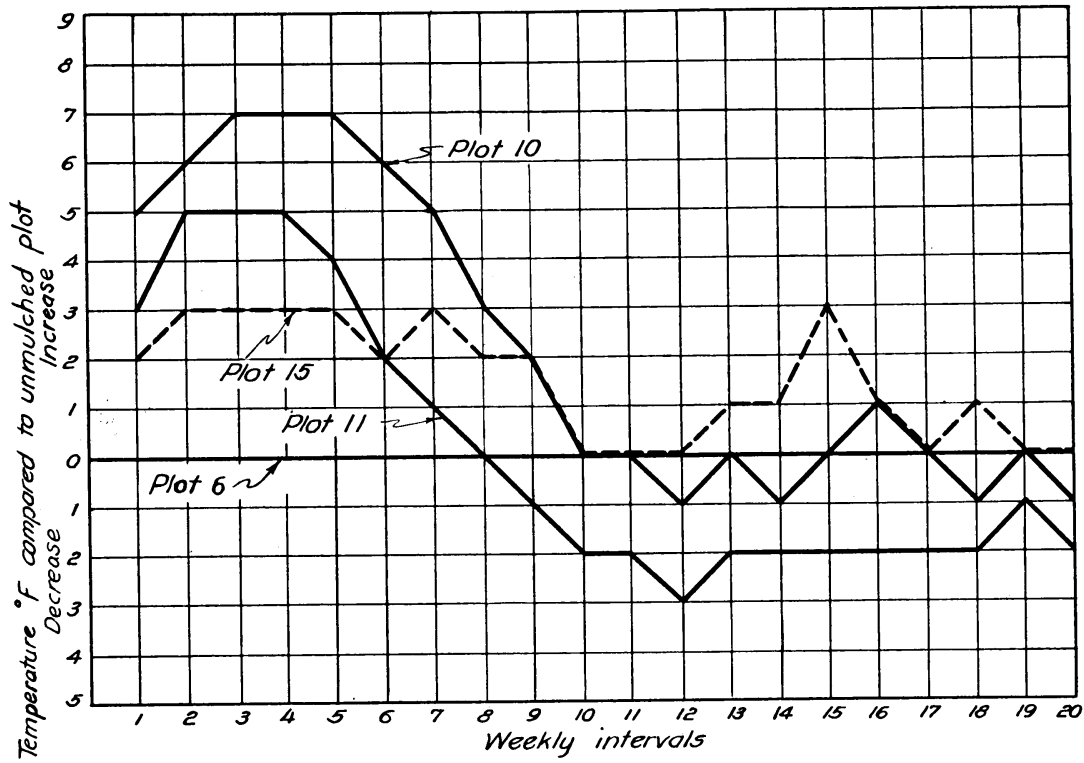

Fig. 26. Effect of paper mulch in the cropped plots at the 12-inch depth during the 1926 season (April 24 to September 2), as shown in the weekly night average temperatures in degrees Fahrenheit, higher or lower than the temperatures of the unmulched plot. Plot 6-Unmulched. Plot 10-Covered completely with Thermo-Gen No. 134, nonperforated. Plot 11-Completely covered with Thermo-Gen No. 234, perforated. Plot 15-Partially covered with Thermo-Gen No. 134, nonperforated.

where no paper mulch was used, the average height of the plants was 9 inches. The average height was 14 inches where the nonperforated paper was used, alike for plots entirely covered and for those only partially covered. The average height was 12 inches where the perforated paper was used, alike for entirely covered and for partially covered plots. On June 18, when the plants were nearly 9 weeks old, the least growth had been made on those plots on which there was no paper mulch and the best growth on those covered entirely with the black nonperforated paper. In the plots where the nonperforated paper was used, the plants made a better growth in the center of the 
row than on the end, the difference in height averaging about 6 inches. In the plots covered with the perforated paper as well as those not covered with paper, the height of the plants in the rows was more uniform. In figure 27 the difference in the height of the plants in the row is apparent in the foreground (plot 10) where the area was completely covered with nonperforated paper.

By July 12 the plants growing on the unmulched plots showed only about one-third as many heads out as those growing on the plots completely covered with nonperforated paper, while in the other plots the plants had headed out from one-half to three-fourths as much as in

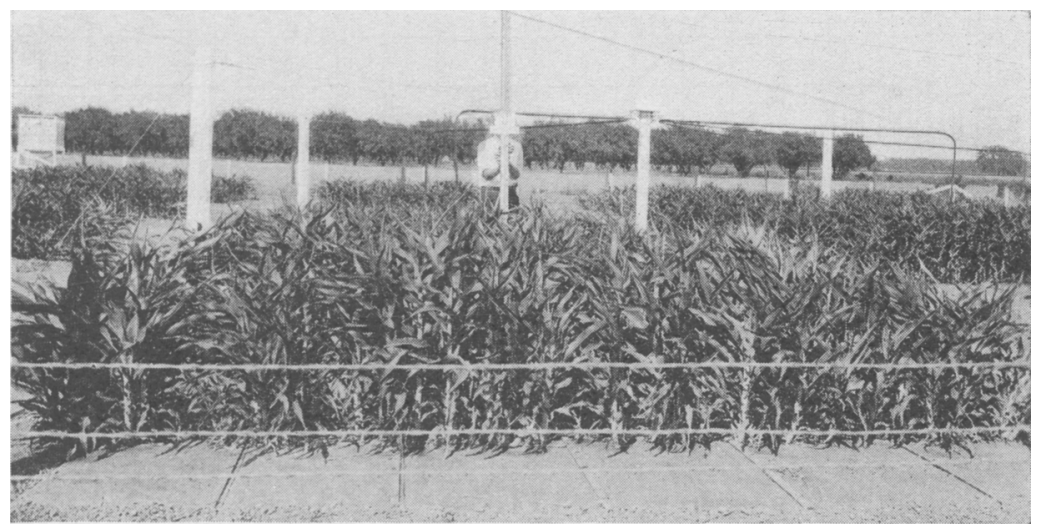

Fig. 27. A grain sorghum (Yolo) in the area completely covered with a black nonperforated paper mulch. June 28, 1926. The plants in the center of the plot made a better growth than those on the ends.

the area completely covered with nonperforated paper. By July 26, when the plants in all of the plots appeared to be completely headed out, the average height in the unmulched plots was 40 inches and in the paper-mulched plots 45 to 50 inches. The greatest height being in the area which was completely covered with nonperforated paper.

Birds were doing some damage to the crop by July 26 , when the grain was in milk, and it appeared necessary to cover each row with cheesecloth and there was little damage from this source after that date. Figure 28 is a view of the plots after they had been covered with cheesecloth. The crop was harvested in early September, the yields for certain plots being reported by Gilmore. ${ }^{(1)}$ In referring to plots 10 and 11, he showed that the average yields per plant of total produce (oven-dry matter) on these two plots was, for the nonperforated paper 28.4 per cent greater than the unmulched plot, and for the perforated paper 19.3 per cent greater. The average height 
of the culms grown on the nonperforated paper plot was 21.1 per cent greater, and on the perforated paper plot 15.2 per cent greater than on the unmulched plot. The average weight of the grain per plant on the nonperforated paper plot was 10.3 per cent greater and on the perforated paper plot 3.1 per cent greater than on the unmulched plot. Smith, ${ }^{(1)}$ using the averages of the triplicated plots, stated that where the soil was completely covered with nonperforated paper there was a material increase in the weight of heads, leaves, suckers, and grain.

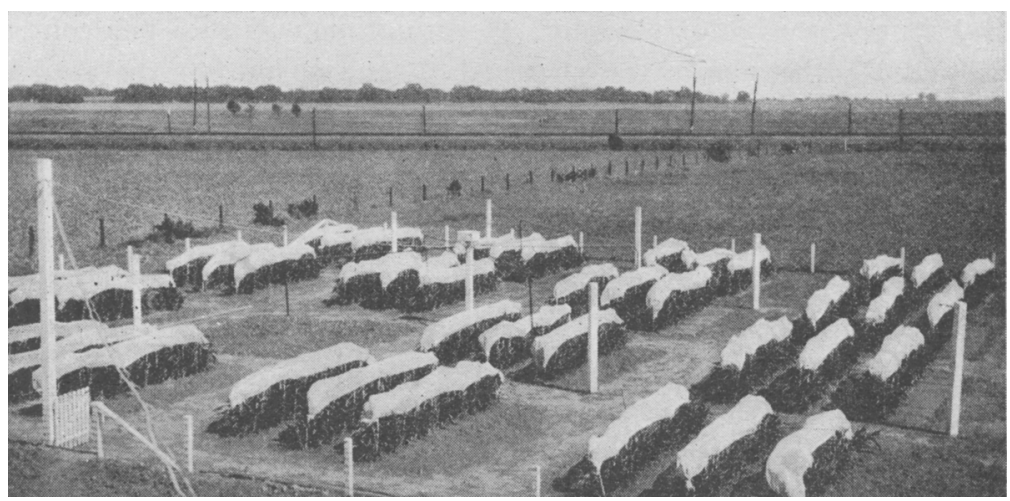

Fig. 28. Appearance of the plots after the rows had been covered with cheeseloth to prevent bird damage.

Placing the value of the yields on the unmulched plots at 100 , the yields on the others were 126.8 for those completely covered with nonperforated paper; 110.7 for those completely covered with perforated paper; 105.8 for those partially covered with perforated paper, and 90.2 for those partially covered with nonperforated paper. Attention is again called to the fact that in certain sections of the plots partially covered with nonperforated paper, sand and gravel are present at a depth of $5 \frac{1}{2}$ feet, which may have influenced the yield adversely:

\section{PAPER MULCH TRIALS IN 1927}

All of the plots were spaded 8 inches deep on November 1, 1926, a total rainfall of 2 inches having fallen since the previous crop had been harvested in September. The thermometers were left undisturbed in the same locations as during the previous years. The plots were stirred by raking on February 1, and again on March 8, 1927, by which time a total of 15 inches of rain had fallen. 
Potatoes Used as the Indicator Crop in 1927.-On March 8 seed tubers produced from tuber-indexed potatoes, and dipped for 1 hour in bichloride of mercury, was planted, and the temperature data herein recorded begin at sunrise on March 9 . At the time of planting, the soil was in a good structural condition, being well granulated and having a favorable moisture content. Where the seed was large, it was cut into four to six portions with two eyes to each. The seed was planted 14 inches apart in rows 3 feet apart. The last plant in the row was 6 inches from the edge of the plot and the outside rows were 2 feet from the edge of the plot. Germination was 97.5 per cent and on April 25, the plants were rogued to one sprout to the seed and sprayed for aphis. The paper mulch was applied on April 27 and 28.

TABLE 3

Effect of Various Surface Treatments on Yield and Shape of Potatoes in 1927

\begin{tabular}{|c|c|c|c|c|}
\hline Plot No. & Surface treatment & $\begin{array}{c}\text { Average } \\
\text { weight of } \\
\text { potatoes } \\
\text { per plant }\end{array}$ & $\begin{array}{c}\text { Average } \\
\text { number of } \\
\text { potatoes } \\
\text { per plant }\end{array}$ & $\begin{array}{c}\text { Average } \\
\text { ratio of } \\
\text { equatorial } \\
\text { diameter } \\
\text { to polar } \\
\text { diameter }\end{array}$ \\
\hline & & grams & & \\
\hline $6,9,13$ & Unmulched, cultivated once a month & 87 & 1.76 & 0.78 \\
\hline $1,10,14$ & $\begin{array}{l}\text { Completely covered with nonperforated black paper } \\
\text { mulch, Pabco Thermo-Gen No. 124.............. }\end{array}$ & 149 & 2.55 & 0.71 \\
\hline $2,11,12$ & $\begin{array}{l}\text { Completely covered with perforated black paper } \\
\text { mulch, Pabco Thermo-Gen No. 224............................... }\end{array}$ & 127 & 2.00 & 0.72 \\
\hline $3,4,15$ & $\begin{array}{l}\text { 9-inch strip of nonperforated black paper mulch, Pabco } \\
\text { Thermo-Gen No. 124, on either side of crop row.............. }\end{array}$ & 105 & 1.76 & 0.74 \\
\hline $5,8,16$ & $\begin{array}{l}\text { 9-inch strip of perforated black paper mulch, Pabco } \\
\text { Thermo-Gen No. 224, on either side of crop row............. }\end{array}$ & & 1.68 & 0.77 \\
\hline
\end{tabular}

Plot Treatments in 1927.- The treatment of the plots during this season is shown in table 3. Six plots were completely covered with paper mulch, while on six others a 9-inch strip of paper mulch was used on both sides of the crop row. Both types of paper mulch used were asphalt impregnated and coated and were black on both sides. The nonperforated black paper was Thermo-Gen No. 124, contained 900 square feet per roll, weighing 72 pounds, and costing $\$ 1.95$. The perforated paper was Thermo-Gen No. 224, contained 900 square feet per roll, weighing 81 pounds, and costing $\$ 2.00$. The perforations were 4 inches apart in the rows and the rows were $3 \frac{1}{2}$ inches apart. The perforations were $U$-shaped and $7 / 16$ of an inch deep. Although there were several rains after the paper was laid, no pools were formed on any of the plots, all of the water having passed through the per- 
forations or other openings in the paper. There was no permanent distortion of the papers as the result of the rain.

Moisture Determinations in 1927 Season.-As previous results indicated that the conservation of moisture by paper mulch was confined largely to the surface 4 inches of soil under the conditions (nonirrigated) of these experiments, soil samples from the surface foot were taken by 4-inch sections, and for the second to sixth foot inclusive by 12 -inch sections. As the dry season advanced each year, it was noted that beads of moisture would appear on the under side of the nonperforated paper, and the surface 4 inches of soil was much more moist than the 4-8 or 8-12 inch sections. This would indicate that the accumulation of moisture was due to movement in the vapor phase with condensation on the paper. The condition was noted whether or not crops were being grown.

The first sampling for moisture determinations was made on March 21, the second on May 16, the third on June 11, after a rainfall of 0.47 inch which came on May 27-28, and the last sampling was made on June 20, after the potatoes were harvested. At the first sampling, the soil to the full depth of 6 feet in all the plots was found to be moist to field capacity except in the surface 4 inches in which it was about 2 per cent below field capacity. By May 16, in all the cropped plots except those completely covered with paper mulch, the moisture content of the surface 4 inches of soil averaged about 12 per cent of the oven-dry weight of the soil. In plots 1, 10, and 14, which were completely covered with nonperforated paper, the moisture content averaged 14.67 per cent and in plots 2, 11, and 12, which were completely covered with perforated paper, it was 13.83. On June 11 the moisture content of the surface 4 inches in all the plots was approximately the same (slightly less than 12 per cent). At harvest time, June 20, in all the plots except those completely covered with paper mulch, the moisture content of the surface 4 inches averaged 7.30 per cent, while in plots 1,10 , and 14, which were completely covered with nonperforated paper, it averaged 13.62 per cent, and in plots 2,11 , and 12 , which were completely covered with perforated paper, it averaged about 13 per cent. The moisture changes in the surface 4 inches, that is, differences in the moisture content between the first and last sampling, show that in all the plots except those completely covered with paper, the loss of moisture was approximately the same (from 10.37 to 10.95 per cent based on the oven-dry weight of the soil) while in the plots completely covered with paper the loss was approximately one-half of this amount. 
Between the first and last samplings there was a moisture loss in the 4-8 inch section of from 6.76 per cent to 8.46 per cent based on oven-dry weight of the soil, and the loss on any particular date was practically the same regardless of the surface treatment. In the 8-12 inch section by May 16, slightly greater losses of moisture had occurred in the plots completely covered with paper mulch than in the others, probably because, as will be shown later, the potato plants in these plots were more vigorous. By harvest time the moisture losses for the season at this depth ranged from 6.65 per cent to 7.58 per cent based on oven-dry weight of the soil. In the second, third, fourth, fifth, and sixth-foot depths there were no appreciable differences in the moisture content of the variously treated plots on any of the dates of sampling. In the uncropped plot, No. 7, which was hoed 4 inches deep once a month, the moisture loss in the surface 4-inch section was nearly 11 per cent based on oven-dry weight of the soil, in the 4-8 inch section slightly over 6 per cent, and in the 8-12 inch section nearly 5 per cent. In the second and third foot the losses were 3 per cent and 1 per cent respectively. The greatest changes, as can be seen from the above, were in the surface foot of soil. Slight changes in the moisture content of the soil of the second foot and deeper were usually found as the dry season advanced, probably owing to movement of moisture in the vapor phase.

Soil Temperatures in 1927.-Temperature data were obtained from planting time to harvest with the electrical resistance thermometers in the same locations (plots 6, 7, 10, 11, and 15) and under the same conditions as during the previous two seasons. As has been shown by the author, ${ }^{(14)}$ distinct seasonal temperature changes occurred in the area under investigation to a depth of 3 feet.

From the temperature data the average day and night temperatures were determined in the cropped plots. At a depth of 3 inches, the soil temperatures in the various plots, up to the time when the paper mulch was put on, were within $1^{\circ} \mathrm{F}$ of each other. During the 7 weeks following the application of the paper mulch, where the 9 -inch strips of nonperforated paper were used, the average day temperatures were only $1^{\circ}$ higher than in the unmulched cropped plot. Where the nonperforated paper covered the entire plot, the average soil day temperatures were $6^{\circ}$ higher, and where the perforated paper was placed over the entire plot they were from $3^{\circ}$ to $4^{\circ} \mathrm{F}$ higher than in the unmulched cropped plot. No temperatures were obtained where the strips of perforated paper were used.

The average night temperatures at a depth of 3 inches in the various cropped plots, before the paper mulch was put on, were within $1^{\circ} \mathrm{F}$ 
of each other. After the paper mulch was put on the average night temperature at the 3 -inch depth, where the 9-inch strips of nonperforated paper were used, were $2^{\circ}$ to $3^{\circ}$ higher, and where the nonperforated paper completely covered the plot, it was $7^{\circ}$ higher than in the unmulched cropped plot. Where the perforated paper was used, covering the entire plot, it was $4^{\circ}$ to $5^{\circ} \mathrm{F}^{*}$ higher than in the unmulched cropped plot.

The average day and night temperatures at the 12-inch depth in the various cropped plots before the paper mulch was put on were usually within $1^{\circ} \mathrm{F}$ of each other. After the paper mulch was put on, in the plots with the 9-inch strips of nonperforated paper, the average

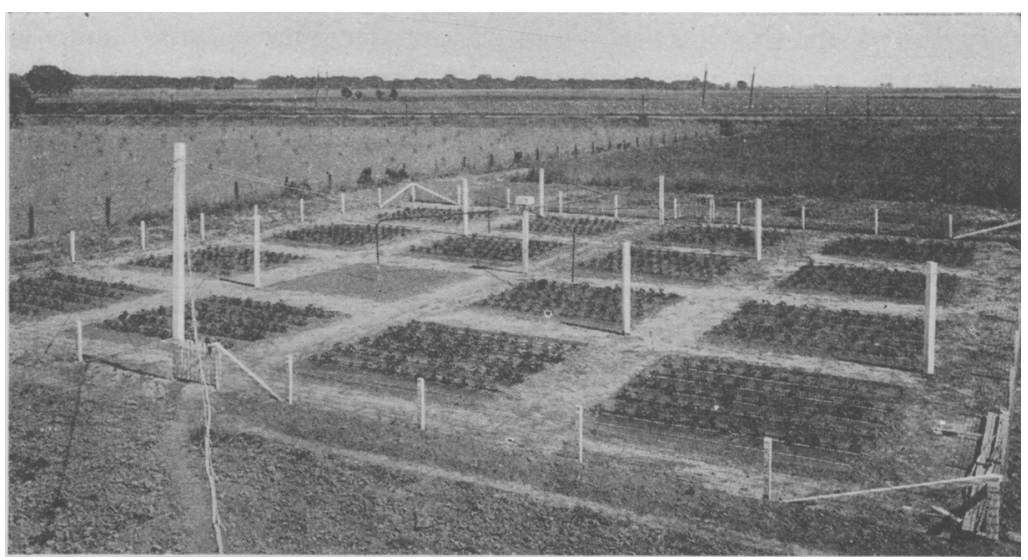

Fig. 29. The experimental area on May 12, 1927, showing potato plants after the paper mulch had been applied. The plots are numbered from right to left beginning with the bottom tier.

day and night temperatures were $1^{\circ}$ higher, and where the nonperforated paper covered the plot completely, they were $5^{\circ}$ higher than in the unmulched cropped plot. Where the perforated paper mulch completely covered the plot, the temperatures were $4^{\circ}$ higher than in the unmulched cropped plot. After applying the paper mulch, the weekly average day and night temperatures at the 3 -inch and 12-inch depths, in the various plots, ranged from $69^{\circ}$ to $91^{\circ} \mathrm{F}$.

Rate of Crop Growth in 192\%.-The condition of the potato plants on May 12 is shown in figure 29. This view was taken about 2 weeks after the paper mulch was applied. On May 14 a careful survey of the condition of the potato plants showed that 95 per cent were thrifty, 3 per cent were weak, and the balance had failed to grow or had been removed because of serious injury from aphis. Between May 14 and harvest, it was necessary to remove more plants because 
of fusarium wilt, aphis, and damage by gophers. By June 7, on the unmulched and on all of the partially covered plots, the potatoes were maturing and the leaves were starting to turn brown. On the six plots completely covered with paper, all the plants were green and apparently still growing. The earliest maturing plants were on the unmulched plots. The harvesting of the potatoes was started on June 20 and completed 2 days later, although 90 per cent of the plants in the plots completely covered with paper were still green. In the plots completely covered with nonperforated paper mulch, about 5 per cent of the potatoes were found on the soil directly underneath the paper. In all the other plots they developed below the surface of the soil. The potatoes produced by the end plants of each row were not included in the harvest data. Because some plants had been removed, the average number harvested per plot was 56, with a minimum of 51 , and a maximum of 60 .

The effect of the various surface treatments on the number of potatoes and the average weight of potatoes per plant is summarized in table 3.

With the cooperation of the late Dr. J. T. Rosa of the Division of Truck Crops, measurements of all the potatoes produced were made in order to determine what effect the various surface treatments had made on the shape of the potatoes. Two dimensions were obtained, $E D$, equatorial diameter, and $P D$, polar diameter, and the ratio $\frac{E D}{P D}$ determined (table 3). A study of this table will show that in the plots which were completely covered with paper mulch the potatoes were more slightly elongated than in the other plots. These are the plots having the higher soil temperatures. Similar observations have been made by others, as for instance, Jones, Johnson, and Dickson, ${ }^{(7)}$ who in 1926 pointed out that "A temperature of $18^{\circ} \mathrm{C}$ gave the best or normal shape of potatoes, whereas at the higher temperatures, the tubers tend to become elongated and pear-shaped," and Werner ${ }^{(17)}$ in 1929 found that "the low-temperatured tubers were more nearly round, having ratios of width to length varying from 1.00 to 1.25 , whereas the similar ratios of the high temperature tubers generally were less than 1.00 , indicating relatively a considerable degree of elongation." Werner also found that soil temperatures materially affected the color of the seed tubers but had no significant influence upon the productivity. 


\section{PAPER MULCH TRIALS IN 1928}

All of the plots were spaded 8 inches deep on June 23, 1927, and again on February 10, 1928, and then hoed 4 inches deep on March 10, 1928. The thermometers were undisturbed and in the same locations as during the previous years.

Potatoes Used as the Indicator Crop in 1928.-On March 13 and 14 , potatoes were planted in fifteen of the sixteen plots. The seasonal rainfall up to this time amounted to 11.03 inches. Seed of the White Rose variety, produced in Riverside County, California, was used because it was more uniform than the seed used during the previous season. The seed potatoes were dipped for 1 hour in bichloride of mercury, and since they were large, they were cut into from three to six pieces with two eyes to each. The distance of the planting and the depth was the same as during the previous season. On April 17 the plants were thinned to one sprout per seed and then hilled. On this date, after removing the weak plants, the stand was 96 per cent. The missing plants were replaced by transplanting from another part of the area, and the paper mulch was applied to the plots on May 4. No spraying for aphis was necessary during this season. The potatoes started to bloom on May 14.

Plot Treatments in 1928.--Four types of paper mulch were used during this season. The one designated as Asparagus Mulch paper weighed 100 pounds per roll of 900 square feet. The second was called Summer Mulch paper, Pabco Thermo-Gen No. 142, 900 square feet per roll, weighing 25 to 30 pounds. The third type was labeled Pabco Thermo-Gen No. 224 perforated, weighing 81 pounds per roll of 900 square feet. The fourth type was called Pabco Thermo-Gen No. 134, weighing 81 pounds per roll of 900 square feet. The cost of these papers ranged from $\$ 1.93$ per roll for the Summer Mulch paper, the lightest, to \$3.53 per roll for the Asparagus Mulch paper, the heaviest. All of these paper mulches with the exception of the Asparagus Mulch paper, were black on both sides. The latter was black on one side and gray on the other. The paper mulch was applied on May 4, each treatment being replicated on three plots. The Asparagus Mulch paper was placed with the black side up. It will be noted that only one paper, Pabco Thermo-Gen No. 224, was perforated. The three plots which were not mulched with paper were cultivated 4 inches deep once a month. The surface treatments of the various plots in 1928 are shown in table 4. 
Moisture Determinations in 1928.-When the paper mulch was put on, the surface 6 feet of soil contained moisture up to field capacity. During the early season, beads of moisture collected on the under side of the paper mulch, particularly where the nonperforated types were used, but at harvest time there was no evidence of this.

\section{TABLE 4}

Soil-Moisture Changes Based on Differences Between the Moisture Content at the First and Last Sampling in the Uncropfed Plot Compared to the Cropped Plots in 1928

\begin{tabular}{|c|c|c|c|c|c|c|c|}
\hline \multirow{2}{*}{ Plot No. } & \multirow{2}{*}{ Plot treatment } & \multicolumn{6}{|c|}{$\begin{array}{c}\text { Moisture lost expressed as a percentage of oven-dry } \\
\text { weight of soil }\end{array}$} \\
\hline & & $\begin{array}{c}0-4 \\
\text { inches }\end{array}$ & $\begin{array}{c}4-8 \\
\text { inches }\end{array}$ & $\begin{array}{l}8-12 \\
\text { inches }\end{array}$ & $\begin{array}{l}12-24 \\
\text { inches }\end{array}$ & $\begin{array}{r}24-36 \\
\text { inches }\end{array}$ & $\begin{array}{l}36-48 \\
\text { inches }\end{array}$ \\
\hline 7 & Uncropped plot..................... & 9.33 & 6.73 & 4.56 & 3.33 & 2.08 & 2.10 \\
\hline $2,6,13$ & $\begin{array}{l}\text { Unmulched, cultivated once a } \\
\text { month, cropped }\end{array}$ & 15.99 & 10.78 & 9.55 & 10.13 & 9.45 & 7.91 \\
\hline $1,10,16$ & $\begin{array}{l}\text { Asparagus Mulch paper, nonperfo- } \\
\text { rated, black side up, cropped......... }\end{array}$ & 15.42 & 10.35 & 10.17 & 10.22 & 9.59 & 7.59 \\
\hline $3,11,14$ & $\begin{array}{l}\text { Pabco Thermo-Gen No. 142, non- } \\
\text { perforated, black on both sides, } \\
\text { cropped }\end{array}$ & 15.96 & 10.93 & 10.31 & 10.10 & 8.98 & 8.92 \\
\hline $4,5,15$ & $\begin{array}{l}\text { Pabco Thermo-Gen No. 134, nonper- } \\
\text { forated, black on both sides, } \\
\text { cropped. }\end{array}$ & 14.36 & 10.85 & 10.53 & 10.21 & 9.98 & 8.35 \\
\hline $8,9,12$ & 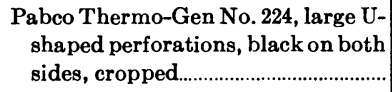 & 14.55 & 10.46 & 10.26 & 10.55 & 9.19 & 6.21 \\
\hline
\end{tabular}

In table 4 the moisture changes based on differences between the moisture content at the time of the first sampling, April 24, and the final sampling on June 25 are shown. These figures are the averages of four samples each from triplicated plots, and four for the uncropped area. No significant differences were found in the moisture losses of the cropped plots for the same depth at these dates of sampling. The greatest differences were in the $36-48$ inch section.

Soil-moisture determinations were also made of the $0-6$ inch and 6-12 inch sections on May 4 and June 4, at which dates soil-nitrate tests were also made. On May 4 there was no appreciable difference in the moisture content in the cropped plots for the surface foot of soil. On June 4 the moisture content of the $0-6$ inch section in the paper-mulched plots averaged from 2.10 per cent to 2.56 per cent higher (based on oven-dry weight of soil), and in the 6-12 inch section from 0.65 per cent to 1.37 per cent higher than in the unmulched cropped plots. The perforated paper used in the 1928 season compared favorably with the nonperforated paper, for the flaps were not distended by any 
heavy rains, and therefore there was no great circulation of air through the paper. At harvest time the plants in all of the plots were mature, while this was not true in the previous season.

Soil-Nitrate Determinations in 1928.-The nitrate content of the soil was determined by the phenol-disulfonic acid method at the times indicated above, from four locations in each plot and from a composite for each plot from the 0-6 and 6-12 inch sections. On May 4 the nitrate content $\left(\mathrm{NO}_{3}\right)$ of the 0-6 inch section in the cropped plots, those covered with paper mulch, and those unmulched, averaged from 10 to 17 parts per million of soil and 29 parts in the uncropped plot. One month later the nitrate content in the cropped plots in the $0-6$ inch section averaged from 12 to 20 parts per million of soil, while in the uncropped plot it averaged 49 parts. On May 4 , in the 6-12 inch section of the cropped plots, the nitrate content averaged from 15 to 18 parts and in the uncropped plot 30 parts per million of soil. One month later for the same depth in the cropped plots the nitrate content averaged from 3 to 8 parts, and in the uncropped plot 30 parts per million of soil. There were no consistent differences in the nitrate content of the various cropped plots. No nitrate tests were made of the growing plant material.

Soil Temperatures in 1928.-Temperature data were obtained with the electrical resistance thermometers in the same locations as during the previous three seasons. The temperatures for each thermometer were recorded continuously every 15 minutes and the average day and night temperatures were determined from these. Before the paper mulch was put on, the average temperatures at the 3-inch depth in the cropped plots were within $1^{\circ} \mathrm{F}$ of each other, while after the paper mulch was put on, they were sometimes $3^{\circ} \mathrm{F}$ higher under the paper than in the unmulched cropped plot. This was only true, however, during the first 4 weeks after the paper mulch was put on. After that time the differences were not so great. The weekly day and night average temperatures in the cropped plots at a depth of 12 inches were practically the same before and after the paper mulch was put on.

The average day and night temperatures at the 3 -inch and 12-inch depth during this season (1928) were from $3^{\circ}$ to $5^{\circ} \mathrm{F}$ higher than in 1927. As will be shown later, a more uniform and vigorous crop was obtained in 1928 than in 1927, which was doubtless primarily due to the better seed potatoes used (see fig. 30 ).

Crop Yields in 1928.-At harvest time, in June, the end plants and two of the weakest remaining plants in each row were discarded. The 
total number of plants harvested per plot was 58 . From table 5 it will be seen that yields as high as 315 grams of potatoes per plant were produced under the paper mulch, while during the previous season (1927) the highest yield per plant was 149 grams.

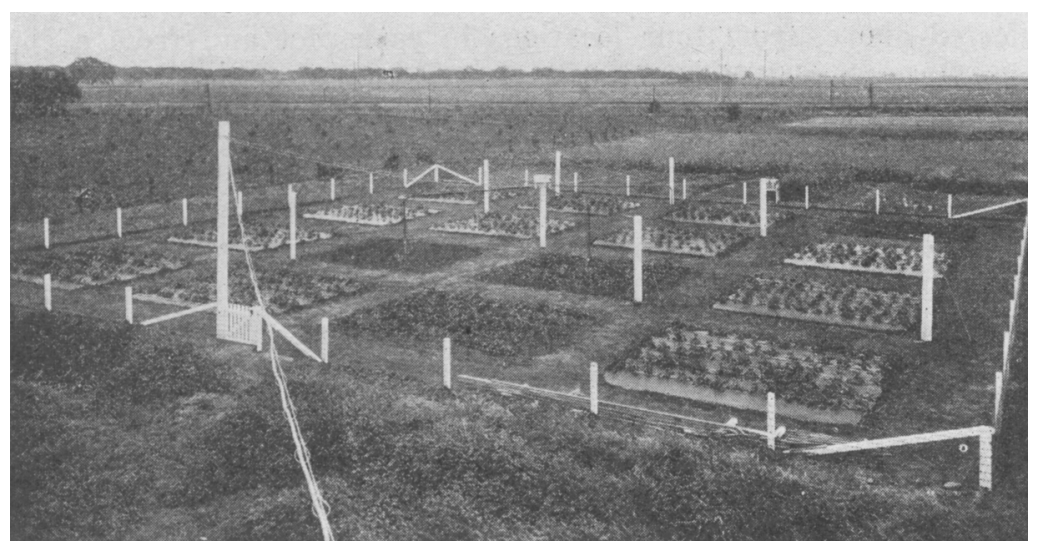

Fig. 30. Experimental area showing potato plants on May 8, 1928. The three unmulched cropped plots and the uncropped plot are readily discernible.

TABLE 5

Effect of Various Surface Treatiments on Yield and Shape of Potatoes in 1928

\begin{tabular}{|c|c|c|c|c|}
\hline Plot No. & Surface treatment & $\begin{array}{c}\text { Average } \\
\text { weight of } \\
\text { potatoes } \\
\text { per plant }\end{array}$ & $\begin{array}{c}\text { Average } \\
\text { number of } \\
\text { potatoes } \\
\text { per plant }\end{array}$ & $\begin{array}{l}\text { Average } \\
\text { ratio of } \\
\text { equatorial } \\
\text { diameter } \\
\text { to polar } \\
\text { diameter }\end{array}$ \\
\hline $2,6,13$ & Unmulched, cultivated once a month... & $\begin{array}{c}\text { grams } \\
272\end{array}$ & 4.10 & 0.72 \\
\hline $1,10,16$ & Asparagus Mulch paper, nonperforated, black side up & 299 & 4.42 & 0.69 \\
\hline $3,11,14$ & $\begin{array}{l}\text { Pabco Thermo-Gen No. 142, nonperforated, black on } \\
\text { both sides }\end{array}$ & 315 & 4.06 & 0.68 \\
\hline $4,5,15$ & $\begin{array}{l}\text { Pabco Thermo-Gen No. 134, nonperforated, black on } \\
\text { both sides. }\end{array}$ & 294 & 4.52 & 0.68 \\
\hline $8,9,12$ & $\begin{array}{l}\text { Pabco Thermo-Gen No. 224, large U-shaped perfora- } \\
\text { tions, black on both sides......... }\end{array}$ & 278 & 4.00 & 0.70 \\
\hline
\end{tabular}

These data show that in those plots where the nonperforated or perforated paper mulch was used, the potatoes produced had a slightly lower ratio, $\frac{E D}{P D}$ than in the unmulched plots. The results obtained during this season on the $\frac{E D}{P D}$ ratio were comparable to those obtained during the 1927 season. No particular difference could be 
determined in either the 1927 or 1928 season in the firmness of the potatoes produced under the various conditions. Werner ${ }^{(17)}$ has pointed out, however, that potatoes produced under low temperatures are firmer than those produced under high temperatures.

Effect of Paper Mulches Used in Previous Years on Fenugreek Crop in 1929.-After the potatoes were harvested in June, 1928, the plots were spaded 8 inches deep and the soil left rough until November of that year when a winter cover crop of fenugreek was planted in all of the plots except No. 7, which had been kept free of plant growth since the start of these experiments. The rate of growth for the fenugreek was very slow owing to the abnormally cold spring. By March 11, 1929, it was only 6 inches high, but by April 11 it had reached a height of 22 inches. When turned under, in April, 1929, the green growth averaged 23,311 pounds per acre and there was no evidence from the rate of growth or total amount of green plant material produced in the various plots that the previous use of paper mulch on some of them had any effect on this crop of fenugreek.

\section{SUMMARY}

Paper-mulch experiments, extending over a period of four years, on a brown loam soil, at Davis, California, show that during the dry season of the year, under unirrigated conditions, the nonperforated black paper was the most effective in conserving moisture. This effect, however, was confined to the surface 4 inches of soil, and was due to condensation of water underneath the paper.

The greater proportion of the surface covered by paper, the more positive was the effect on the soil moisture, soil temperature, and crop yield. Black papers raised the soil temperatures, whereas gray papers reduced them. Where the paper was perforated the entire width of the strip, the soil temperatures were the same as or lower than the unmulched plots, according to the color of the paper used.

Very little weeding was necessary where the entire area of the plots was covered with nonperforated paper mulch, but where the perforated types were used, some weeding was necessary.

With a grain sorghum (Yolo) one season and potatoes for two seasons as indicator crops, it was found that paper mulches gave a slight increase in yield. Measurements indicated that the potatoes produced at higher temperatures, such as were induced by the use of black paper mulch, were more elongated and pear-shaped than those produced at lower temperatures. 
The use of paper mulch except on small areas does not seem feasible at the present time because of the initial cost of the paper and its application, and the extra time necessary in planting and caring for the crop (spraying, etc.) in order to avoid undue injury to the paper.

\section{LITERATUURE CITED}

1 California Agricultural Experiment Station.

1927. Report of the Agricultural Experiment Station of the University of California from July 1, 1926, to June 30, 1927, 44, 91.

2 Edmond, J. B.

1929. Muleh paper for vegetable crops is tested. Michigan Agr. Exp.

3 Fint, L. H. Sta. Quart. Bul. 2:115-117.

1928. Crop-plant stimulation, with paper mulch. U. S. Dept. Agr. Tech. Bul. 75:1-20.

4 Flint, L. H.

1929. Suggestions for paper mulch trials. U. S. Dept. Agr. Cir. 77:1-8. 5 Harding, S. T.

1919. Relation of the moisture equivalent of soils to the moisture properties under field conditions of irrigation. Soil Sci. 8:303-312.

6 Hartung, W. J.

1926. The functions of paper mulch on pineapple culture. Hawaiian Pineapple Company, Ltd.

7 Jones, L. R., James Johnson, and James G. Dickson.

1926. Wisconsin studies upon the relation of soil temperature to plant disease. Wisconsin Agr. Exp. Sta. Research Bul. 71:1-144.

8 KINCER, J. B.

1916. Daytime and nighttime precipitation and their economic significance.

U. S. Mo. Weather Rev. $44: 628-633$.

9 MAGRUder, Roy.

1930. Paper mulches for the vegetable garden. Ohio Agr. Exp. Sta. Bul. 447:1-60.

10 Mason, S. C.

1925. The inhibitive effect of direct sunlight on the growth of the date palm.

Jour. Agr. Research 31:455-469.

11 Shaw, Charles F.

1926. The effect of a paper mulch on soil temperature. Hilgardia 1: 341-364.

12 Shaw, C. F., and Alf'Red Smith.

1927. Maximum height of capillary rise starting with soil at capillary saturation. Hilgardia 2:399-410.

13 Smith, Alfred.

1927. The effect of mulches on soil temperatures during the warmest week in July, 1925. Hilgardia 2:385-397. 
14 Smith, Alfred.

1929. Comparisons of daytime and nighttime temperatures. Hilgardia 4:241-272.

15 Stewart, G. R., E. C. Thomas, and John Horner.

1926. Some effects of mulching paper on Hawaiian soils. Soil Sci. 22:35-58. 16 Veihmeyer, F. J.

1927. Some factors affecting the irrigation requirements of deciduous orchards. Hilgardia 2:125-284.

17 WeRNER, H. O.

1929. Relative productivity of seed potatoes grown under various controlled environmental conditions. Jour. Agr. Research. 38: 405-410.

Transmitted August, 1930. 